\title{
Yurtdışında Bir Kültür Kurumu: Londra Halkevi
}

\author{
Arş. Gör. Hakan YAŞAR*
}

\begin{abstract}
$\ddot{O}_{z e t}$
19 Şubat 1932 tarihinde açılan halkevlerinin başlıca kuruluş amaçları arasında Atatürk ilke ve devrimlerini geniş halk kitlelerine iletmek ve benimsetmek, milli kültür öğelerini araştırmak, aynı ideali paylaşan insanlar için sosyal merkez oluşturmak ve toplumun her kesiminden insanın kaynaşmasını temin etmek yer almaktadır. Türkiye'nin dört bir tarafinda faaliyet gösteren önemli kültür ve halk ĕ̌̆itimi kurumları olan halkevlerinin sayısı, kapatıldıkları 1951 yılında biri yurt dışında olmak üzere 478'e kadar ulaşmıştır.

Yurtdışında açılan ilk ve tek halkevi olan Londra Halkevi, 19 Şubat 1942

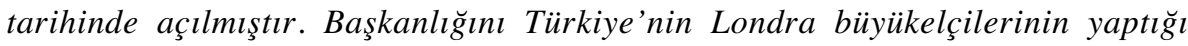
Londra Halkevi'nin kuruluş amaçları arasında; çeşitli etkinlikler düzenlemek suretiyle Türkiye’yi ve Türk kültürrünü Ingilizlere tanıtmak, iki ülke arasındaki kültürel ilişkileri geliştirmek, çeşitli nedenlerle Ingiltere'ye giden Türk vatandaşlart için sosyal bir merkez oluşturmak bulunmaktadır. Londra Halkevi'nde, özellikle 1942-1945 yılları arasında, Türkiye’yi ve Türk kültürünü tanıtmaya yönelik sergiler açılmış, birçok konferans ve Türkçe dersleri verilmiş, film gösterimi yapılmış ve özel günlerde çeşitli etkinlikler düzenlenmiştir. 1946 yllından itibaren işlevini önemli ölçüde yitiren Londra Halkevi, 31 Mart 1950 tarihinde resmen kapatılmıştır.
\end{abstract}

Anahtar Kelimeler: Londra Halkevi, Halkevleri, British Council Türk-İngiliz İlişkileri

\section{A Cultural Enstution Abroad: London People Hause}

\section{Abstract}

Among the main goals of establishment of People's Houses founded in February 19, 1932 were to convey Ataturk's Principals and Revolutions to people in masses and to get them accepted, to search for the components of national culture,

*Ankara Üniversitesi, Türk İnkılâp Tarihi Enstitüsü 
to form a social center for those who shared the same ideal and to secure fusion between people from every sect of the society. The number of People's Houses, which carried out cultural and public education as a significant facility all over Turkey, reached 478, including one abroad, in 1951 when they were closed down.

London People House, the only People House abroad, was opened in February 19, 1942. Among the goals of establishment of London People House led by Turkish ambassadors in London, through performing diverse activities, were to introduce Turkey and Turkish culture to the English, to improve cultural relations between the two countries, and to create a social center for Turkish citizens who attained there for different purposes. In London People House, especially between 1942 and 1945, exhibitions were opened to advertize Turkey and Turkish culture, lots of conferences were held and Turkish language classes were offered, films shown and activities performed on special days. London People House, which lost its function in great deal from 1946 onwards, was officially closed down in March 31, 1950.

Key Words: London People House, public hauses, British Council, TurkishEnglish relations

\section{GİRIŞ}

Cumhuriyet Halk Partisi'nin (CHP) 1931 yılında gerçekleştirdiği III. Büyük Kurultayı'nda kurulma kararı alınan ve ilk olarak 19 Şubat 1932 tarihinde 14 il merkezinde açılan halkevleri, kapandıkları 1951 yılına kadar geçen sürede Türkiye'nin dört bir tarafında faaliyet gösteren önemli kültür ve halk eğitimi kurumlarıdır.

Türkiye'de açılan halkevleri şimdiye kadar pek çok çalışmaya konu edilmişken, yurt dışında açılan ilk ve tek halkevi olma özelliğine sahip olan "Londra Halkevi"nin kuruluş süreci, faaliyetleri ve kapatılma sürecini aydınlatacak bir çalışma yapılmamıştır ${ }^{1}$. Ayrıca, CHP ve halkevlerinin yayınlarında da bu halkevinin faaliyetlerine çok az yer verildiği görülmektedir. Bu bağlamda, bizim bu çalışmadaki amacımız; Londra Halkevi'nin kuruluş süreci ve amaçları, idari yapısı, gerçekleştirdiği faaliyetler ve kapatılma sürecini arşiv belgeleri 1 şı̆̆ında ${ }^{2}$ aydınlatmaya çalışmaktır.

${ }^{1}$ Bizim tespit edebildiğimiz kadarıyla Londra Halkevi'ne ilişkin yapılan tek çalışma Meral Demirel'in “İkinci Dünya Savașı'nın Propaganda Dergileri Vanguard ve Cephe'de Londra Halkevi" başlıklı makalesidir. Söz konusu makalede yalnızca bu iki dergide Londra Halkevi'yle ile ilgili çıkan haber ve fotoğraflardan derleme yapılmıștır. Bkz: Meral Demirel, “İkinci Dünya Savaşı'nın Propaganda Dergileri Vanguard ve Cephede Londra Halkevi”, Tarih ve Toplum, S.232, C.39, Nisan 2003.

${ }^{2}$ Biz bu çalıșmamızı hazırlarken büyük ölçüde Başbakanlık Cumhuriyet Arşivi'nde bulunan Londra Halkevi Başkanlığı ve Londra Büyükelçiliği’nin CHP Genel Sekreterliği ile ilgili çeşitli yazışmaları, Londra Halkevi’nin faaliyet ve teftiş raporları, halkevinin genel 
Londra Halkevi'ne geçmeden önce, konunun daha iyi anlaşılması ve diğer halkevleriyle Londra Halkevi arasında bir karşılaştırma yapılabilmesi amacıyla, Türkiye'de kurulan halkevleri hakkında genel bilgi vermenin yararlı olacağı kanaatindeyiz. Halkevlerinin kuruluşunda dönemin siyasi, ekonomik ve sosyo-kültürel gelişmelerinin büyük etkisi olmuş, söz konusu etkiler aynı zamanda halkevlerinin kuruluş amaçlarını da büyük ölçüde şekillendirmiştir. Halkevlerinin kurulduğu 1932 tarihine kadar geçen süre Türk siyasi hayatı açısından çok önemli dönüm noktaları yaşanmıştır. Bu süreç içerisinde saltanat ve hilafet kaldırılmış, cumhuriyet ilan edilmiş, yeni bir anayasa hazırlanmış, toplumsal hayata ilişkin pek çok yenilik getirilmiş ve bu surette yeni rejimin büyük ölçüde şekillenmesi temin edilmiştir. Ayrıca yine bu süreçte Șeyh Sait isyanı bastırılmış ve Terakkiperver Cumhuriyet Fırkası gibi ülkede baş gösteren muhalif yapılanmalar ortadan kaldırılmıştır ${ }^{3}$. Yani, Mustafa Kemal Atatürk'ün devrimci eyleminin kurumsallaşma dönemi, önemli ölçüde tamamlanmış ve artık cumhuriyet ideolojisi doğrultusunda yeni bir toplum yaratmak için uygulama safhasına geçmenin zamanı gelmiştir ${ }^{4}$.

1929 yılına gelindiğinde, ülkede siyasi istikrar temin edilmiş olmasına karşın halkın ekonomik durumunda önemli bir iyileşme sağlanamamıştır. Ayrıca 1929 'da patlak veren Dünya Ekonomik Buhranı, savaşın yaralarını sarmaya çalışan ülkedeki ekonomik durumu daha da ağırlaştırmıştır. Ekonomik krizin ülkede kendini iyice hissettirmeye başladığ 1930 yılı ise halkevlerinin alt yapısının hazırlanmaya başladı $\breve{g} 1$ dönem olmuştur. Söz konusu ekonomik krizin de etkisiyle ülke genelinde huzursuzluk hâkim olmaya başlamıştır. Halkevlerinin kuruluşunda, ekonomik krizin ülkede geniş çaplı tartışmalar meydana getirmesi ve halk ile devlet arasındaki uçurumun daha da derinleşmesinden endişe duyan yönetimin, halk arasında yeni bir heyecan uyandırmak ve halk ile devlet arasındaki mevcut kopukluğu giderme fikri etkili olmuştur ${ }^{5}$.

1930 yılında Serbest Cumhuriyet Fırkası (SCF) ile hayata geçirilmeye çalışılan çok partili sistem denemesi önemli siyasal sonuçlar doğurmuştur. SCF'nin kısa süredeki gelişimi ve halktan gördüğü ilgi, bu partinin başlangıçta öngörüldüğü şekilde bir "parlamento içi denetim organı" olmadı̆̆ını, parlamento dışında gelişen ve kitle partisi hüviyeti kazanmaya başladığını; aynı zamanda, CHP iktidarının ciddi bir alternatifi olduğunu

durumuyla ilgili hazırlanan raporlar, halkevinin bütçe hesapları ve kapatılış sürecine ilişkin belgelerden istifade ettik.

${ }^{3}$ Sefa Simsek, Bir Ídeolojik Seferberlik Deneyimi Olarak Halkevleri 1932-1951, Boğaziçi Üniversitesi Yayınevi, İstanbul 2002, s.28.

${ }^{4}$ Emre Kongar, Atatürk ve Devrim Kuramları, Türkiye İş Bankası Kültür Yayınları, Ankara 1981, s.351.

${ }^{5}$ Anıl Çeçen, Atatürk'ün Kültür Kurumu Halkevleri, Cumhuriyet Yayınları, İstanbul 2000, s.91-92. 
göstermesi açısından önemlidir ${ }^{6}$. SCF ile çok partili hayata geçiş denemesi, 1930 yılı öncesinde gerçekleştirilen devrimlerin halk tarafından benimsenme derecesini göstermesi açısından da önemli bir deneyim olmuş ve SCF'nin kısa süre içindeki gelişimi göz önüne alındığında, devrimlerin halk tarafından yeterince benimsenmediği ya da başka bir ifadeyle CHP tarafından benimsetilmekte yetersiz kalındığı sonucu ortaya çıkmıştır?

$\mathrm{Bu}$ gelişmeler, CHP'yi toplumla ilişkilerini yeniden yapılandırma sürecine sokacaktır. Bu sürecin istenilen amaç doğrultusunda başarıya ulaşması için doğrudan halkla temas halinde bulunacak, bütün bir sosyal hayata hitap edecek ve yurdun her yerinde faaliyet gösterecek, cumhuriyetin temel prensiplerini geniş halk kitlelerine iletecek ve benimsetecek kurumlara ihtiyaç duyulmuş, halkevleri de bu temel ihtiyacı karşılamak üzere kurulmuşlardır.

Halkevlerinin kuruluşunda etkili olan bir diğer gelişme ise Menemen olayı gibi gericilik olaylarının bir daha yaşanmaması ve bu tip olayların halk tabanında destek görmemesi için halkın cumhuriyet ilkeleri doğrultusunda belirli bir bilinç düzeyine ulaştırılmasına hizmet edecek yaygın halk eğitimi kurumlarına ihtiyaç duyulmasıdır. Nitekim halkevlerinin kuruluş ve işleyiş̧ esaslarını tespit eden 1932 tarihli Halkevleri Talimatnamesi'nde Menemen Olayı'na açık bir vurgu yapılması ${ }^{8}$ bunun açık göstergelerinden biridir. Halkevlerinin kuruluş kararının alınmasında etkili olan bir diğer etmen ise, çok uluslu bir imparatorluk yapısından ulus devlete geçiş sürecinin yeni bir toplumsal dönüşümü gerekli kılmasıdır. Yüzlerce yıllık bir imparatorluk tecrübesinden gelen geleneksel toplumun hem çağdaş bir anlayışla ulus seviyesine yükseltilmesi hem de çağdaşlaşma sürecini idrak etmesi gerekmiş̧iri?.

Halkevlerine verilen en temel görevler; Atatürk ilke ve devrimlerini geniş halk kitlelerine yaymak ve benimsetmek ${ }^{10}$ suretiyle kalıcı olmalarını temin etmek; milleti, birbirini anlayan birbirini seven ve aynı ideale bağlı bir halk kütlesi halinde teşkilatlandırmak ${ }^{11}$, halk arasında yaşayan milli kültür öğelerini araştırmak, aynı idealler etrafında toplanacak insanlar için bir sosyal merkez oluşturmak, toplumun her kesiminin birbiriyle kaynaşmasını

${ }^{6}$ Esat Öz, Otoriterizm ve Siyaset, Türkiye'de Tek Parti Rejimi ve Siyasal Katılma (1932-1945), Ankara 1996, s.86-87.

${ }^{7}$ Öz, a.g.e., s. 88

${ }^{8}$ CHF Halkevleri Talimatnamesi, Hâkimiyet-i Milliye Matbaası, 1932, s.1-2; CHP Halkevleri Ö̆grene ği, Recep Ulusoğlu Basımevi, Ankara 1938, s.4.

9 Mustafa Ozodaşık, Cumhuriyet Dönemi Yeni Bir Nesil Yetiştirme Çalışmalar 1923-1950, Çizgi Kitabevi, Konya 1999, s.249-250.

${ }^{10}$ Nafi Atuf Kansu, "Halkevlerimiz", Ülkü, C.XIII, S.73, Mart 1939, s.7.

11 "Recep Bey'in Nutku”, Hâkimiyeti Milliye, 20 Şubat 1932. 
temin etmek ve gençleri "zararlı fikir akımları"ndan koruyarak ${ }^{12}$ Kemalist ilkeler doğrultusunda eğitmektir.

Halkevleri, kuruluşlarını takip eden ilk birkaç yıllık süre içerisinde gerek nicelik gerekse nitelik bakımından oldukça gelişmiş ve bu kuruluşların gerçekleştirmiş olduğu faaliyetlere milyonlarca kişi katılmıştır. Halkevlerinin kısa sürede ülkenin başlıca kültür ve halk eğitim merkezleri haline gelmesinde CHP'nin payı büyüktür. Çünkü devletin bütün imkânları bu kuruluşların başarılı çalışmalar yürütebilmesi için seferber edilmiştir.

Halkevi şubeleri bütün bir sosyal ve kültürel hayata hitap edebilecek ölçüde geniş bir çalışma sahasına sahiptir. Halkevlerinin çok geniş bir çalışma sahasına sahip olmasında bu kuruluşların açılışından önce faaliyet gösteren birçok derneğin feshedilmesinden doğan boşluğu kapatmak ve bütün sosyo-kültürel faaliyetlerin CHP'nin kontrolünde ve tekelinde yürütülmesi amacı yatmaktadır. Halkevleri şu çalışma şubelerinden meydana gelmiştir: 1) Dil, Tarih ve Edebiyat Şubesi, 2) Güzel Sanatlar Şubesi, 3) Temsil Şubesi 4) Spor Şubesi, 5) Sosyal Yardım Şubesi, 6) Halk Dershaneleri ve Kurslar Şubesi, 7) Kütüphane ve Neşriyat Yayın Şubesi, 8) Köycülük Şubesi, 9) Müze ve Sergi Şubesi ${ }^{13}$. 1939 yılına gelindiğinde halkevlerinin sayısı 379'a ulaşırken, bir yerde halkevi açılabilmesi için asgari şartları sağlayamayacak kadar küçük olan yerleşim birimlerine halkodaları açılması kararı alınmıştır ${ }^{14}$.

Çok partili hayata geçişle birlikte, tüzel kişiliği bulunmaksızın CHP’ye bağlı bir kültür kolu olarak faaliyetlerini sürdüren ve devlet bütçesinden önemli yardımlar alan halkevleri ve halkodalarının mevcut durumu, CHP ve Demokrat Parti arasında önemli bir tartışma konusu olmuştur. Bu süreçte, yaşadığı maddi sıkıntılar nedeniyle işlevini önemli ölçüde kaybetmeye başlayan halkevlerine CHP tarafından yeni bir hukuki kimlik kazandırılması ve çok partili hayatın gereklerine uydurmaya yönelik birtakım teşebbüslerde bulunulmasına karşın bu çabalar sonuçsuz kalmıştır. 1950 yılında DP'nin iktidara gelmesi ile birlikte halkevleri ve halkodaları artık kapatılma sürecine girmiş ve 8 Ağustos 1951 yılında kabul edilen 5830 sayıll yasa ${ }^{15}$ ile bu kuruluşların bütün mallarına el konulmak suretiyle halkevleri kapatılmıştır. Kapatıldıklarında halkevlerinin sayısı 478 , halkodalarının sayısı ise 4.322'ye kadar yükselmiştir.

\footnotetext{
${ }_{12}^{12}$ Süleyman Kazmaz, "Halkevleri ve Gençlik", Ülkü, S.58 (Yeni Seri), Mart 1944, s.13.

${ }_{13}$ CHF Halkevleri Talimatnamesi, s.3-4; CHP Halkevleri Öğreneği, s.5; CHP Halkevleri İdare ve Teşkilat Talimatnamesi, Zerbamat Basımevi, Ankara 1940, s.4.

${ }_{15}^{14}$ CHP Halkevleri ve Halkodaları 1943, Ankara 1944, s.3.

${ }_{15}$ T.B.M.M. Tutanak Dergisi, C.9, Dönem IX, Toplantı 1, T.B.M.M. Basımevi, Ankara 1951, s.741; 5830 sayılı yasanın tam metni için bkz: T.C. Resmi Gazete, 11 Ağustos 1951, s.7882, s.1781-1782.
} 


\section{Londra Halkevi’nin Açılıșı ve Kuruluş Amaçları}

\section{a. Londra Halkevi'nin Açılıș Süreci}

Aralık 1939'da meydana gelen Erzincan depreminde zarar gören depremzedelere yardım amacıyla gerek yurt içinde gerekse yurt dışında çeşitli çalışmalara gidilmiştir. İngiltere'den de Erzincan depremzedelerine yapılan yardım işlerini incelemek üzere, "Londra Yardım Komitesi" adına Türkiye'yi ziyaret eden General Sir Wyndham Deeds, bazı halkevlerini de ziyaret etmiştir. Deeds, Şubat 1940'da yaptığı geziler sırasında Türkiye'deki gelişmelerden oldukça etkilenmiş̧tir. Deeds, Türkiye'de yaptığ 1 incelemelerde; modern Türkiye'de yapılan devrimlerin İngilizler tarafından henüz yeterince bilinmediğini, diğer taraftan İngiltere'nin mevcut sosyal ve kültürel durumundan da Türklerin yeterince haberdar olmadığ varmıştır. General Deeds, 12 Şubat 1940 tarihinde CHP Genel Sekreterliği'ne yazdığı mektubunda; Türkiye'deki halkevlerinin çalışmalarını incelediğini; sosyal ve kültürel sahada önemli çalışmaları olan bu kurumların her zümreye ait vatandaşları bünyesinde toplamayı başardığını ve böyle bir kurumun Türk-İngiliz kültürel ilişsilerini ve dostluğunu geliştirmek için oluşturulabileceğini ifade etmiş ve Londra'da "örnek bir halkevi” açılmasını teklif etmiştir. Deeds, yine aynı mektubunda, böyle bir halkevinin British Council'den ${ }^{16}$ yapılacak belirli bir yardıma ilave olarak İngiltere'deki Türk severler ile bazı cemiyetler tarafından yapılacak yardımlar vasıtasıyla işletilebileceğini ifade etmiştir ${ }^{17}$.

Başbakan Refik Saydam, Deeds'in mektubuna verdiği cevapta; Türkİngiliz dostluğunun pekiştirilmesi ve her iki milletin birbirini tanıması için böyle bir teşebbüsün yerinde oluğunu ifade ederek gereken teşebbüste bulunulması için genel sekreterliğe talimat verdiğini belirtmiştir ${ }^{18}$.

${ }^{16}$ İlk kez 1934 yılında "Diğer Ülkelerle İlişkiler İçin İngiliz Komitesi” adıyla faaliyetlerine başlayan British Council, bizzat İngiliz Dışişleri Bakanlığı tarafından kurulmuştur. Kuruluş amaçları resmi olarak eğitim ve kültür alanında faaliyet göstermek ve kurulduğ üu ülkelerle İngiltere'nin kültürel ilişsilerini geliştirmek olarak açıklanan British Council, kısa sürede birçok ülkeye şube açmıştır. British Council, 1940 yılından bu yana Türkiye'de de faaliyet göstermekte olup, şu an Ankara ve İstanbul'daki şubelerinin yanı sıra ülkenin pek çok yerinde faaliyet göstermektedir. Bkz: http://www.britishcouncil.org/new/BritishCouncil75th/

Başbakanlık Cumhuriyet Arşivi (BCA), 490.01/ 1065.1086.1 (Zelzele felaketzedelerine yardım için kurulan Türk-İngiliz Komitesi Mümessili Sir Wyndham Deeds tarafından 12 Şubat 1940 tarihinde CHP Genel Sekreterliği'ne gönderilen mektup); $B C A$, 490.01/1065.1086.1 (CHP Genel Sekreteri Dr. A. F. Tuzer tarafından Londra Büyükelçisi Tevfik Rüştü Aras'a gönderilen 24. 4. 1940 tarihli yazı)

${ }^{18}$ BCA, 490.01/1065.1086.1 (Dr. Refik Saydam tarafından "Zelzele Felaketzedelerine Yardım İçin Kurulan Türk-İngiliz Komitesi” Mümessili Sir Wyndham Deeds'e 14.2.1940 tarihinde gönderdiği yazı); $B C A, 030.10 / 117.817 .21$ (Londra Halkevi'nin mevcut durumu hakkında CHP Genel Sekreterliği'nin 13.11.1946 tarihli raporu). 
Londra'da bir "Türk Halkevi” açılmasına karar verildikten sonra 4 Mayıs 1940 tarihinde CHP Genel Sekreterliği'nden Londra Büyükelçiliği'ne gönderilen yazıda, Londra'da açılması düşünülen halkevinin bina, bütçe, yönetmelik ve eleman meselelerini görüşmek üzere iki İngiliz ve üç Türk’ten meydana gelecek bir kurulun oluşturulması istenmiştir ${ }^{19}$. Bu talimat üzerine, 28 Kasım 1941 tarihinde Londra Büyükelçisi Tevfik Rüştü Aras başkanlığında oluşturulan Londra Halkevi'nin ilk idare kurulunda; British Council Başkanı Sir Robertson, General Deeds ile Türkiye'nin Londra Başkonsolosu ve Kültür Ataşesi yer almıştır ${ }^{20}$.

İdare kurulu tarafından Londra Halkevi'nin açılışının 19 Şubat ${ }^{21} 1942$ tarihine yetiştirilebilmesi için öncelikte, British Council tarafından halkevine bir bina temin edilmesi ve her yıl 250 sterlin verilmesi kararlaştırılmıştır. Diğer masrafların karşılanması için ise CHP'den 1.300 sterlin gönderilmesi istenmiştir. Yine halkevinin açılış hazırlıkları kapsamında gerekli olan bazı eşyalar Londra'ya gönderilmiştiti2 ${ }^{22^{3}}$.

Londra Halkevi, açılış için gerekli olan bütün hazırlıklar bitirildikten sonra 19 Şubat 1942 tarihinde gerçekleştirilen bir törenle açılmıştır. Törene, başta İngiliz Dışişleri Bakanı Anthony Eden ve bazı bakanlar olmak üzere birçok devlet adamı katılmıştır²3.

\section{b. Londra Halkevi Binast}

Londra'da Fitzhardinge Caddesi'nde bulunan halkevinin ilk binası, üç yıllığına British Council tarafından kiralanmış ve kira bedeli yine bu kuruluş tarafından karşılanmıștır. Ancak İkinci Dünya Savaşı'nın tüm şiddetiyle devam ettiği yıllarda Londra Halkevi de zor zamanlar yaşamıştır. 14 Mart 1944 tarihinde Londra'ya yapılan Alman hava hücumu sırasinda Londra Halkevi'ne de yangın bombaları isabet etmiş ve binada yangın çıkmıştır. Halkevi bekçisinin çabaları neticesinde yangın kısa sürede söndürülmüşse de halkevi binasının iki katı hasar görmüştür ${ }^{24}$.

${ }^{19}$ BCA, 490.01/1065.1086.1 (CHP Genel Sekreteri ve Kırklareli Milletvekili N. Kansu tarafından 11.2.1946 tarihinde Başbakan Şükrü Saraçoğlu'na sunulan rapor)

${ }^{20} B C A, 490.01 / 1065.1086 .1$ (Londra Büyükelçiliğ̈i'nden CHP Genel Sekreterliği’ne gönderilen telgraf); BCA , 490.01/1065.1086.1 (CHP Genel Sekreteri ve Kurklareli Milletvekili N. Kansu tarafından 11.2.1946 tarihinde Başbakan Şükrü Saraçoğlu'na sunulan rapor)

${ }^{21}$ Türkiye'de halkevleri ilk olarak 19 Subat'ta açıldı açılış yıldönümü olarak büyük bir coşkuyla kutlanmış ve yeni açılacak olan halkevlerinin 19 Şubat tarihinde açılmasına özen gösterilmiştir.

${ }_{22}$ BCA, 490.01/1065.1086.1 (CHP Genel Sekreterliği'nden Londra Büyükelçiliği'ne 31.1.1941 tarihinde gönderilen yazı)

${ }^{23} B C A, 490.01 / 1065.1086 .1$ (CHP Genel Sekreteri ve Kırklareli Milletvekili N. Kansu tarafından 11.2.1946 tarihinde Başbakan Şükrü Saraçoğlu'na sunulan rapor).

${ }^{24} B C A, 490.01 / 1064.1084 .1$ (Dışişleri Bakanlığ 1 'ndan CHP Genel Sekreterliği'ne 18 Mart 1944 tarihinde yazılan yazı) 
Halkevi binasının kira sözleşmesinin dolduğu 24 Aralık 1944 tarihinden sonra British Council'den yapılan kira yardımı kesilmiş, ayrıca 1944 yılında gelindiğinde halkevinin üye sayısının 300'e yükselmesi ${ }^{25}$ ve mevcut halkevi binasının gerçekleştirilen faaliyetler için yetersiz oluşu nedeniyle ${ }^{26}$ yeni bir bina arayışına gidilmiştir. Yapılan uzun araştırmalar neticesinde Hindistan Eski Genel Valisi Lord Linlidghow'un evi olan oldukça büyük ve gösterişli bir bina, Mayıs 1946 tarihinde 10.500 sterlin karşılığında 52 yıllığına kiralanmıştır ${ }^{27}$. Londra'nın en merkezi yerlerinden birinde olan ${ }^{28}$ yeni bina, halkevinin bütün ihtiyaçlarını karşılayabilecek büyüklüktedir ${ }^{29}$. Londra Halkevi, kapandığı tarihe kadar 43 Belgrave Square adresinde bulunan ikinci binasında faaliyet göstermiştir ${ }^{30}$. Halkevi kapandıktan sonra ise bu bina önce Londra Büyükelçiliği'ne daha sonra da Hükümet'e devredilmiştir.

\section{c. Londra Halkevi’nin Kuruluş Amaçları}

Türkiye'de kurulan halkevlerinin kuruluş amaçları CHP tarafından hazırlanan idare ve çalışma yönetmeliklerinde ve halkevlerinin yayınlarında açıkça belirtilmekle birlikte, Londra Halkevi için aynı şeyi söylemek mümkün değildir. Londra Halkevi, gerek yurtdışında olması gerekse hitap ettiği kitlenin niteliği nedeniyle Türkiye'de bulunan diğer bütün halkevlerinden farklı kuruluş amaçlarına sahiptir. Londra Halkevi Başkanlığı ile CHP Genel Sekreterliği arasındaki yazışmalardan, Londra Halkevi'nin fikir babası diyebileceğimiz Sir Wyndham Deeds'in CHP Genel Sekreterliği'ne gönderdiği mektuplardan ve Londra Halkevi'nin gerçekleştirdiği faaliyetlerden halkevinin kuruluş amaçlarını tespit etmek mümkündür.

Londra'da bir halkevi kurulması fikrini ortaya atan ve Londra Halkevi'nin kurulmasına önemli ölçüde katkı sağlayan İngiliz Milli ve Sosyal Cemiyetleri Birliği İkinci Başkanı Sir Wyndham Deeds, 12 Şubat 1940 tarihinde CHP Genel Sekreterliği’ne gönderdiği mektupta kurulması istenen halkevinden beklenen yararları şu şekilde ifade etmiştir:

${ }^{25}$ BCA, 490.01/1065.1086.1 (Londra Büyükelçiliği'nden CHP Genel Sekreterliği'ne gönderilen 29.2.1944 tarih ve 61 sayllı şifre tel sureti)

26 BCA, 490.01/1065.1086.1 (Londra Halkevi Başkanı Ruşen Eşref Ünaydın'ın 27.03.1945 tarihinde CHP Genel Sekreterliği'ne halkevinin mevcut durumu ile ilgili sunduğu rapor)

${ }^{27}$ BCA , 490.01/1065.1086.1 (Londra Halkevi Başkanlığı tarafından CHP Genel Sekreterliği’ne 7.6.1946 tarihinde gönderilen rapor)

${ }^{28}$ BCA, 490.01/1065.1086.1 (CHP Kars Milletvekili Tezer Taşkıran'ın 3.12.1946 tarihinde CHP Genel Sekreterliği'ne sunduğu rapor)

${ }^{29} B C A, 490.01 / 1065.1086 .1$ (Londra Halkevi Başkanı Ruşen Eşref Ünaydın'ın 27.03.1945 tarihinde CHP Genel Sekreterliği'ne halkevinin mevcut durumu ile ilgili sunduğu rapor)

${ }^{30}$ BCA, 490.01/1065.1086.1 (Londra Halkevi Başkanlığ 1 tarafından 1.7.1947 tarihinde CHP Genel Sekreterliği'ne sunulan idare heyeti raporu) 
“Londra'da açılacak halkevi Türkiye'yi Ingilizlere tanıtmak ve Ingiltere'yi Türklere tanıtmak için de lazım gelen materyali toplamak ve mübadele vazifesi ile mükellef bir merkez olacă̆ gibi, Ingiltere'de Türkiye hakkında herhangi bir mevzu için yahut terakkiyat hakkında malumat edinmek isteyenlere bir vasita olabilecektir. Londra Halkevi'nde ayn zamanda Türk kültürü ve sosyal hareketleri hakkında konferanslar vermek, sinemalar göstermek, Türk musiki konserleri vermek, buna mümasil çalışmalarda bulunmak suretiyle büyük fayda ve randıman temin edebileceğini; Türkiye'den İngiltere'ye gelen Türk seyyahlara lazım gelen suhuleti göstermek, Ingiltere'de tahsilde bulunan Türklerin toplanma merkezi olmak, Türkleri İngiliz dostları ile bir araya toplamaya vasita olacaktır..." ${ }^{\text {3I }}$.

Yine Deeds tarafından 27 Mart 1940 tarihinde CHP yöneticilerine gönderilen mektupta İngiltere'de Türkiye'ye karşı derin bir bilgisizlik olduğundan bahsedilmiş ve açılması düşünülen halkevinin bu bilgisizliği kaldırmada önemli bir rol oynayacağ 1 ifade edilmiştir ${ }^{32}$. General Deeds'in, İngilizlerin Türkiye'ye karşı derin bir bilgisizlik içerisinde olduğu tespitine Londra Halkevi yöneticilerinin de katıldığ 1 görülmektedir ${ }^{33}$.

Deeds'in CHP'ye gönderdiği mektuplardan anlaşıldığı kadarıyla onun halkevinden beklediği temel işlevler; her iki ulusu birbirine tanıtmak suretiyle iki ülke arasındaki kültürel bağları kuvvetlendirmek ve çeşitli sebeplerle İngiltere'ye gelecek olan Türk vatandaşları ile İngilizlerin bir araya gelebileceği bir sosyal merkez oluşturmak olarak özetlenebilir. Buna karşın Londra Halkevi Başkanlığı'ndan CHP Genel Sekreterliği'ne gönderilen çeşitli yazılarda British Council'in Londra Halkevi'nin açılmasından istediği asıl maksadın Türkçe eğitim olduğu ifade edilmiştir ${ }^{34}$.

CHP'nin halkevlerine ilișkin kendi yayınlarından birinde de Londra Halkevi'nin kuruluş amaçları; hem İngiltere'de yaşayan Türklere bir toplanma ve kaynaşma yeri olması hem de Türk inkılâbının özelliklerini

${ }^{31} B C A$, , 490.01/1065.1086.1 (Zelzele felaketzedelerine yardım için kurulan Türk-İngiliz Komitesi Mümessili Sir Wyndham Deeds tarafından 12.2.1940 tarihinde CHP Genel Sekreterliği'ne gönderilen mektup)

${ }^{32} B C A, 490.01 / 1065.1086 .1$ (Sir Wyndham Deeds'in 27.3.1940 tarihli mektubu)

33 Örneğin Londra Halkevi Başkanlığı tarafından 1 Temmuz 1947 tarihinde CHP Genel Sekreterliği'ne sunulan raporda; İngilizlerin büyük bir çoğunluğunun Türklerin kültürleri ve yaşayış tarzları hakkında hiçbir bilgi sahibi olmadıkları; doğuda bulunan ülkeleri ziyaret edip de Türkiye'yi görmemiş olanların da Türkiye'yi diğer doğu memleketleri gibi geri zannettikleri, Türkiye'deki yaşam biçimini hala yüzyıl öncesinde olduğu gibi düşündüklerini ifade edilmektedir. BCA, 490.01/1065.1086.1 (Londra Halkevi Başkanlığ 1 tarafından 1.7.1947 tarihinde CHP Genel Sekreterliği'ne sunulan İdare Heyeti Raporu)

${ }^{34} B C A$, , 490.01/1065.1087.1 (Londra Büyükelçisi H. Rauf Orbay tarafından 16.10.1942 tarihinde CHP Genel Sekreterliği'ne gönderilen yazı); BCA, 490.01/1065.1086.1 (CHP Genel Sekreteri ve Kırklareli Milletvekili N. Kansu tarafından 11.2.1946 yılında Başbakan Şükrü Saraçoğlu'na sunulan rapor) 
İngilizlere tanıtarak iki ülke arasında sıkı ilişkiler kurulması hususunda çalışmalar yapılması olarak ifade edilmiştir ${ }^{35}$.

1944 yılında Londra Büyükelçiliği ve Halkevi Başkanlığı görevini yürüten Ruşen Eşref Ünaydın, başkanlık görevine başladıktan sonra hazırladığı raporda; Londra Halkevi'nin kuruluş ve var olma amacını iki maddeyle özetlemiştir. Bunlardan birincisi; halkevinin, Londra ve İngiltere'nin diğer şehirlerinde bulunan Türk gençlerini bünyesinde toplaması ve ulusal ideallerinin ve kültürlerinin ne olduğunu onlara hatırlatacak bir ulusal bilinç kaynağı olması; ikincisi ise; Yeni Türk Devleti'ni yapılan devrimler yönüyle İngilizlere tanıtmaya çalışarak daha önceden Türk milleti ve Türkiye ile ilgili oluşmuş yanlış düşüncelerin giderilmesi, Türkiye'nin mevcut durumu hakkında her türlü tanıtım materyalinin kullanılarak gerçekçi bilgiler verilmesi ve bir ilim-kültür merkezi haline getirilmesidir ${ }^{36}$.

Yukarıda Londra Halkevi'nin kuruluş amaçlarına ilişkin yaptığımız açıklamalara ek olarak, Londra Halkevi'nin kuruluşunun özellikle İngilizler açısından ne derece siyasi bir amaç taşıdığı sorgulanmalıdır. Çünkü Londra'da bir halkevi açılması fikrinin bizzat İngilizler tarafından ortaya atılması ve Sir Deeds'in bu teklifi yaptığı 1940 yılının ve Londra Halkevi'nin açıldığ 1942 yılının Türk-İngiliz ilişkileri açısından oldukça önemli bir tarih olmasının üzerinde dikkatle durmak gerekir. Söz konusu tarih İngiltere'nin başını çektiği Müttefiklerin, Türkiye'yi kendi yanlarında savaşa sokmak için baskılarının arttığı döneme denk gelmektedir. Bu aşamada İngilizler, Londra Halkevi'ni kendileri açısından bir propaganda merkezi olarak düşünmüş ve bu kuruluşa birtakım siyasi anlamlar da yüklemiş olması muhtemeldir. Bunun yanı sıra British Council gibi bir İngiliz kuruluşunun da Londra Halkevi'nin açılışına önayak olmasının yanı sıra, halkevi binasının üç yıllık kira bedelini karşılaması ve bu kuruluşun 1945 yılına kadar halkevinin idare kurulunda üye bulundurması gerçekten dikkate değerdir.

Londra Büyükelçiliği'nden 1944 yılında CHP Genel Sekreterliği'ne gönderilen bir yazıdan British Council'in Londra Halkevi'ni kendi amaçları doğrultusunda bir propaganda merkezi olarak gördüğünü ${ }^{37}$ ve özellikle de II.

${ }_{36}^{35}$ CHP XVI. Yıldönümünde Halkevleri ve Halkodaları, s. 23.

BCA, 490.01/1065.1086.1 (Londra Halkevi Başkanı Ruşen Eşref Ünaydın'ın 27.03.1945 tarihinde CHP Genel Sekreterliği'ne halkevinin mevcut durumu ile ilgili sunduğu rapor)

${ }^{37}$ Londra Halkevi Başkanlı̆̆ tarafından 7.6.1946 tarihinde CHP Genel Sekreterliği'ne gönderilen raporda, halkevinin British Council'in mali vesayeti altında suni bir propaganda şubesi işlevi gördüğü, British Council'in mali yardımlarının 1944 yılında son bulmasının ardından halkevinin artık kendi haline kaldı $\breve{g} 1$ ifade açıkça ifade edilmiștir. Bkz: $B C A$, 490.01/1065.1086.1 (Londra Halkevi Başkanlığı tarafından CHP Genel Sekreterliği'ne 7.6.1946 tarihinde gönderilen rapor) 
Dünya Savaşı'nın devam ettiği yıllarda bu kuruluş vasıtasıyla Londra'daki Türk diplomat ve vatandaşlarını etkilemeye çalıştığı anlaşılmaktadır. Bununla birlikte Londra Büyükelçiliği, Londra Halkevi'ni mümkün olduğunca bu kuruluşun etkisinden kurtarmaya ve halkevinin bir propaganda vasıtası olarak kullanılmasını önlemeye çalışmıştır. Londra Büyükelçiliği'nden CHP Genel Sekreterliği'ne gönderilen bazı çalışma raporlarında, halkevinde verilen konferanslarda ve yapılan konuşmalarda siyasi konulara değinilmediğinin önemle belirtilmesi $\mathrm{de}^{38}$ bu kuruluşun siyasetin dışında tutulmaya çalışıldığının göstergelerinden biridir.

Yine 1942 tarihinde Londra Büyük Elçiliği'nden CHP Genel Sekreterliği'ne gönderilen bir yazıyla, Londra Halkevi'nin British Council ile olan münasebetlerinin sadece halkevinde düzenlenen Türkçe ve İngilizce kurslarıyla sınırlı kalmasının faydalı, bunun dışındaki ilişkilerin ise mahzurlu olacağının bildirilmesi ${ }^{39}$ Londra Halkevi ile British Council arasındaki mevcut ilişkilerden rahatsızlık duyulduğunun göstergeleri arasındadır.

1944 yılına gelindiğinde Türkiye'nin, yapılan bütün teklif ve baskılara rağmen hala Müttefik Devletlerin yanında savaşa girmemiş olması, Türkİngiliz ilişkilerinin gerginleşmesine sebep olmuştur. Türk-İngiliz ilişkilerindeki bu gerginlik, Londra Halkevi ile British Council arasında da yaşanmış ve British Council Londra Halkevi'ne yaptı̆̆ 1 yıllık yardımları 1 Ocak 1945 tarihinden itibaren sonlandırmış ${ }^{40}$, bu tarihten sonra da halkevi yönetim kurulunda hiçbir İngiliz'e yer verilmemiştir ${ }^{41}$. Yine 1945 yılında İngiliz General Deeds tarafından halkevi için kiralanacak yeni binanın masraflarını karşılamak için gerekli paranın temininde İngiliz kaynaklarına başvurulması önerisinin reddedilmesi ${ }^{42}$ ve 3 Aralık 1946 tarihinde CHP Genel Sekreterliği'ne sunulan raporda ne surette olursa olsun İngiliz kuruluşlarından para yardımının kabul edilmemesi gerektiğinin bildirilmesi ${ }^{43}$ Türk-İngiliz ilişkilerinin seyriyle alakalı görülmelidir.

${ }^{38}$ BCA,, 490.01/1064.1083.3 (Halkevi Kâtibi Ali Rıza Şencan tarafından 31.12.1943 tarihinde halkevi başkanlığına sunulan 1943 Aralık ayı faaliyet raporu)

${ }^{39} B C A, 030.10 / 117.817 .21$ (Londra Halkevi'nin mevcut durumu hakkında CHP Genel Sekreterliği'nin 13.11.1946 tarihli raporu)

${ }^{40}$ Ayni rapor.

${ }^{41}$ BCA, 490.01/1065.1086.1 (Konya Milletvekili Muhsin Adil Binal tarafından Londra Halkevi'nin mevcut durumu ile ilgili 3.5.1949 tarihinde CHP Genel Sekreterliği'ne sunulan rapor); $B C A, 030.10 / 117.817 .21$ (Londra Halkevi'nin mevcut durumu hakkında CHP Genel Sekreterliği'nin 13.11.1946 tarihli raporu)

${ }^{42}$ BCA, 030.10/117.817.21 (Londra Halkevi'nin mevcut durumu hakkında CHP Genel Sekreterliği'nin 13.11.1946 tarihli raporu)

${ }^{43}$ BCA, 490.01/1065.1086.1 (CHP Kars Milletvekili Tezer Taşkıran'ın 3.12.1946 tarihinde CHP Genel Sekreterliği'ne sunduğu rapor) 


\section{Londra Halkevi'nin İdari Yapısı ve İşleyişi}

Londra Halkevi'nin idari yapısı ve işleyişine geçmeden önce bu kuruluşun hukuki kimliği hakkında bilgi vermenin faydalı olacağı kanaatindeyiz. Londra Halkevi, tıpkı Türkiye'deki diğer bütün halkevleri ve halkodaları gibi tüzel kişiliğe sahip olmamış; CHP'nin bir kültür kolu olarak kurulmuştur. Londra Halkevi'nin bir kamu kuruluşu ya da dernek statüsünde olmayışı, bu kuruluşun kapatılmasını kolaylaştıran nedenler arasındadır.

Londra Halkevi'nin yurtdışında bulunması, temsili öneminin büyük olması, kuruluş amaçlarının diğer halkevlerinden farklı olması ve İngiliz vatandaşlarının da halkevine üye olmak istemeleri gibi nedenlerle, Türkiye'deki halkevleri ve halkodalarından ayrı bir talimatname ile yönetilmiştir ${ }^{44}$.

Kuruluşundan kapatılmasına kadar yürürlükte kalan söz konusu talimatname Londra Büyükelçisi ve Halkevi Başkanı Rauf Orbay tarafından hazırlanarak CHP Genel İdare Kurulu'na sunulmuş ve Genel İdare Kurulu'nun 4 Aralık 1942 tarihli toplantısında görüşülerek 4 madde halinde kabul edilmiştir ${ }^{45}$. Söz konusu talimatnameye, zaman içinde ortaya çıkan ihtiyaçları karşılamak için bazı ilaveler de yapılmışıtı ${ }^{46}$.

Londra Halkevi Talimatnamesi şu maddelerden oluşmaktadır:

"1.Halkevi başkanı, CHP Genel İdare Kurulu tarafindan seçilir ve kendine bağlı bir istişare kurulu oluşturur.

2.Halkevi başkanının onayı alınmak suretiyle Ingilizler, halkevine fahri üye olabilirler.

3.Fahri üyeler kendilerince uygun gördükleri bir aidat verirler.

4.Fahri üyeler, halkevi faaliyetlerine iștirak ederler ve halkevi kütüphanesinden istifade edebilirler" ${ }^{\text {"47 }}$.

Türkiye'de açılan halkevleri için oldukça ayrıntılı idare ve çalışma talimatnameleri hazırlanmasına rağmen, Londra Halkevi için dört maddelik kısa bir yönetmelik hazırlanmasına gerekçe olarak, II. Dünya Savaşı'nın getirdiği olağanüstü şartlar gösterilmiş ve savaş sona erdikten sonra halkevi

${ }^{44} B C A, 490.01 / 1065.1086 .1$ (Londra Halkevi'nin mevcut durumu ile ilgili Konya Milletvekili Muhsin Adil Binal tarafından CHP Genel Sekreterliği'ne sunulan tarihsiz rapor)

${ }^{45} B C A, 490.01 / 1065.1086 .1$ (CHP Umumi İdare Heyeti V-180. Toplantısı Tutanağ 1 )

${ }^{46} B C A, 490.01 / 1065.1086 .1$ (Rauf Orbay tarafından 27 Ağustos 1942 tarihinde CHP Genel Sekreterliği'ne gönderilen yazı)

${ }_{47} B C A, 490.01 / 1065.1086 .1 ; B C A, 030.10 / 117.817 .21$ (Londra Halkevi Talimatnamesi); $B C A, \quad 490.01 / 1065.1086 .1$ (CHP Umumi İdare Heyeti V-180. Toplantısı Tutanağı); $B C A$ 030.10/117.817.21 (Londra Halkevi'nin mevcut durumu hakkında CHP Genel Sekreterliği'nin 13.11.1946 tarihli raporu) 
için daha teferruatlı bir idare ve çalışma talimatnamesi hazırlanacağı belirtilmişse $\mathrm{de}^{48}$ bu gerçekleştirilememiştir.

\section{a. Londra Halkevi Başkanları}

Londra Halkevi'nin başlıca iki idare kademesi mevcuttur. İdarenin en başında Londra Halkevi Başkanı bulunmaktadır. Londra Halkevi'nin kuruluş kararı alındığında başkanlığına ilk olarak Londra Büyükelçisi'nin getirilmesi tavsiye edilmiş ve bunun üzerine halkevinin ilk başkanı Londra Büyükelçisi olmuştur. Halkevinin idare yönetmeliğinde halkevi başkanlığgnı büyükelçinin yapacağına dair hiçbir kayıt bulunmamasına karşın, bu bir gelenek haline gelmiş ve halkevi başkanlığ 1 görevini Londra Büyükelçileri yürütmüştürr ${ }^{49}$. Ayrıca, Londra Halkevi Başkanlığı'na, Londra Büyükelçileri atanmakla birlikte; bu atama kararları CHP Genel İdare Kurulu tarafından alınmıştır ${ }^{50}$.

Londra Halkevi’nin ilk başkanlığını "Kurucu Başkan” sıfatıyla Londra Büyükelçisi Tevfik Rüştü Aras yapmış ise de; bu görevi 4 Kasım 1942 tarihinde Aras'tan devralan Büyükelçi Rauf Orbay, Halkevi Başkanlığg Genel İdare Kurulu'nca onaylanan ilk halkevi başkanı olmuştur. Rauf Orbay'dan sonra bu görevi, 13 Nisan 1944 tarihinde Büyükelçi Ruşen Eşref Ünaydın devralmıştır ${ }^{51}$. Ruşen Eşref Ünaydın'ın Atina Büyükelçiliği'ne atanması sebebiyle ${ }^{52}$ Londra Halkevi Başkanlığı'nı 14 Kasım 1945'te Büyükelçi Cevat Açıkalın devralmıştır. Açıkalın, bu görevini Londra Halkevi kapanıncaya dek devam ettirmişti ${ }^{53}$.

Halkevi Başkanı Ruşen Eşref Ünaydın, 1945 yılında CHP Genel Sekreterliği'ne sunduğu raporda; büyükelçinin ve konsolosun işlerinin yoğunluğu nedeniyle halkevine yeterince vakit ayırmasının mümkün olmadığını bildirmiş ve Londra Halkevi'ne bir Türk "mesul müdür" atanmasını talep etmiştir ${ }^{54}$. Ünaydın'ın bu talebi, CHP idaresince 1947

${ }^{48} B C A, 490.01 / 1065.1086 .1$ (Londra Büyükelçisi Rauf Orbay’’n CHP Genel Sekreterliği'ne 11 Kânunusani 1943 tarihli yazısı)

${ }_{49} B C A, 490.01 / 1065.1086 .1$ (Londra Halkevi'nin mevcut durumu ile ilgili Konya Milletvekili Muhsin Adil Binal tarafından CHP Genel Sekreterliği'ne sunulan tarihsiz rapor)

${ }^{50} B C A, 490.01 / 1065.1086 .1$ (CHP Başkâtip Vekili tarafından 17 Nisan 1944 tarihinde CHP Genel Sekreterliği'ne gönderilen yazı)

${ }^{51} B C A, 490.01 / 1065.1086 .1$ (CHP Genel Sekreteri ve Kırklareli Milletvekili N. Kansu tarafından 27 Nisan 1944 tarihinde Londra Büyükelçisi Ruşen Eşref Ünaydın’a gönderilen yazi)

Sekreterliği'ne gönderilen yaz1)

${ }_{53} B C A, 490.01 / 1065.1086 .1$ (Konya Milletvekili Muhsin Adil Binal tarafından Londra Halkevi’nin mevcut durumu ile ilgili 3 Mayıs 1949 tarihinde CHP Genel Sekreterliği’ne sunulan rapor)

${ }_{54}$ BCA, 490.01/1065.1086.1 (Londra Halkevi Başkanı Ruşen Eşref Ünaydın'ın 27.03.1945 tarihinde CHP Genel Sekreterliği'ne Halkevinin mevcut durumu ile ilgili sunduğu rapor) 
yılında gerçekleştirilmiştir. Halkevi idare kuruluna karşı sorumlu olan idare müdürü; yönetim kurulunca kendisine havale edilen kararları yürütmek, hesapların tutulmasını sağlamak ve her üç ayda bir hesap cetvellerinin düzenlemesini yapmakla sorumlu tutulmuştur ${ }^{55}$. Bu tarihten sonra Londra Halkevi'nin idare müdürlüğünü kimlerin yaptığı bilgisine ulaşılamamakla birlikte, halkevi kapatıldığında idare müdürlügüünün Adnan Mahir tarafından yürütüldüğü bilinmektedir ${ }^{56}$.

\section{b. Londra Halkevi Yönetim Kurulları}

Londra Halkevi'nin ikinci idare kademesini "Halkevi Yönetim Kurulu" oluşturmaktadır. Londra Halkevi'nin ilk yönetim kurulu, halkevinin açılışından önce, CHP Genel Sekreterliği'nin 4 Mayıs 1940 tarihli talimatıyla oluşturulmuştur. Söz konusu talimatta; Londra'da açılacak olan halkevinin bütçesinin düzenlenmesi, gerekli personelin tayini, yapılacak program ve faaliyetin denetlenmesi amacıyla, üç Türk ve iki İngiliz’den oluşacak bir idare komitesinin oluşturulması istenmiştir. Söz konusu yazıda, idare komisyonuna başta Türkiye'nin Londra Büyükelçisi ve onun uygun göreceği iki üyenin, İngiliz üyelerin ise General Deeds'in ve British Council'in uygun göreceği adaylardan biri olması istenmiştir ${ }^{57}$.

Genel sekreterliğin talimatı doğrultusunda 28 Kasım 1941 tarihinde oluşturulan halkevinin ilk yönetim kurulunda şu isimler yer almıştır:

1. Büyükelçi Tevfik Rüştü Aras,

2. British Council Başkanı,

3. General Wynham Deeds,

4. Ticaret Ataşesi,

5. Büyükelçilik Başkâtibi ${ }^{58}$.

Halkevinin resmi olarak açılışının yapılmadı̆̆ 1941 'de oluşturulan idare kurulu, Rauf Orbay’ın 1942 yılında Londra Büyükelçiliği'ne atanmasından sonra lağvedilmiş ve istişari mahiyette yeni bir yönetim kurulu oluşturulmuştur. Bu yeni yönetim kurulunda ise Başkonsolos Nebil Akçer,

${ }^{55}$ BCA, 490.01/1065.1087.1 (Londra Büyükelçiliği tarafından 7 Mayıs 1947 tarihinde CHP Genel Sekreterliği'ne Sunulan İdare Heyeti Raporu)

${ }^{56}$ BCA, 490.01/1066.1088.1 (Dışişleri Bakanlığı'ndan 22 Ağustos 1950 tarihinde CHP Genel Sekreterliği'ne yazılan yazı)

${ }^{57} B C A, 030.10 / 117.817 .21$ (Londra Halkevi'nin mevcut durumu hakkında CHP Genel Sekreterliği’nin 13.11.1946 tarihli raporu)

${ }^{58}$ BCA, 490.01/1065.1086.1 (Londra Halkevi'nin mevcut durumu ile ilgili Konya Milletvekili Muhsin Adil Binal tarafından CHP Genel Sekreterliği'ne sunulan tarihsiz rapor); $B C A, 030.10 / 117.817 .21$ (Londra Halkevi'nin mevcut durumu hakkında CHP Genel Sekreterliği'nin 13.11.1946 tarihli raporu) 
Halkevi Kâtibi Ali Rıza Şencan, Sir Wyndham Deeds ve Lady Govers bulunmaktadır ${ }^{59}$.

Londra Halkevi'nin İdare Talimatnamesi'ne göre; halkevinin idare kurulunda iki İngiliz'in yer alması gerekirken, 1944 yılından itibaren British Council tarafından halkevine yapılan yardımların kesilmesinden sonra oluşturulan idare kurullarına İngilizler alınmamıştır ${ }^{60}$. 11 Mart 1947 tarihinde tamamı Türk üyelerden oluşturulan yönetim kurulunda, Basın Ataşesi Başkan Vekili Nuri Eren, Ticaret Ataşesi Fikri Diker, Eğitim Ataşesi Turgut Erem, Büyükelçilik Başkâtibi Ferit İldem ve Ajans Muhabiri İhsan Türemen yer almıştır ${ }^{61}$.

Londra Halkevi'nin Londra Büyükelçiliği'ne devrine ilişkin 5 Nisan 1950 tarihli devir raporunda ise, halkevinin son yönetim kurulunun İdare Heyeti Başkanı Nurettin Polvan, Halkevi Murakıbı Haluk Balkır, İdare Heyeti'nden Bülent Ecevit ve Halkevi Müdürü Adnan Mahir'den oluştuğu bilgisi yer almaktadır ${ }^{62}$. Londra Halkevi'nde idari personelin yanı sıra memur ve hizmetliler de istihdam edilmiştir. 1946 yılında bu kuruluşta çalışanlar arasında kâtip, kapıcı, odacı, hizmetli ve kaloriferci bulunmaktadır ${ }^{63}$.

\section{c. Londra Halkevi'nin Bütçesi ve Mali Yapısı}

Londra Halkevi'nin bütçesiyle ilgili ilk yönetmelik 1 Ocak 1944 tarihinde hazırlanmıştır. Söz konusu yönetmeliğe göre, halkevinin bütçesi Londra Büyükelçisi'nin teklifi ve CHP Genel Sekreterliği'nin onayı ile yürürlüğe girmektedir ${ }^{64}$. "Londra Halkevi'nin Hesap İşlerine Ait Talimat" başlığını taşıyan ve toplam yedi maddeden oluşan halkevi bütçe yönetmeliğinde halkevinin gelirler ve giderleri, hesapların nasıl tutulacağı ve bütçe ile ilgili diğer detaylar yer almaktadır ${ }^{65}$.

${ }^{59} B C A, 490.01 / 1065.1087 .1$ (Londra Büyükelçisi H. Rauf Orbay tarafından 16.10.1942 tarihinde CHP Genel Sekreterliği'ne gönderilen yazı)

${ }_{60} B C A, 490.01 / 1065.1086 .1$ (Londra Halkevi'nin mevcut durumu ile ilgili Konya Milletvekili Muhsin Adil Binal tarafından CHP Genel Sekreterliği'ne sunulan tarihsiz rapor)

${ }^{61} \boldsymbol{B C A}, 490.01 / 1065.1087 .1$ (Londra Büyükelçiliğgi tarafından 7.3.1947 tarihinde CHP Genel Sekreterliği'ne sunulan idare heyeti raporu); $B C A, 490.01 / 1065.1086 .1$ (Konya Milletvekili Muhsin Adil Binal tarafından Londra Halkevi'nin mevcut durumu ile ilgili 3.5.1949 tarihinde CHP Genel Sekreterliği'ne sunulan rapor)

${ }^{62} B C A, 490.01 / 1066.1088 .1$ (Dişişleri Bakanlığı'ndan 22 Ağustos 1950 tarihinde CHP Genel Sekreterliği'ne yazılan yazı)

${ }_{63} B C A, 490.01 / 1065.1086 .1$ (Londra Büyükelçiliği'nin halkevi hakkındaki 7.6.1946 tarihli yazısında bildirilen kadro)

${ }^{64}$ BCA, 490.01/1065.1086.1; BCA, 490.01/1065.1087.1 (Londra Halkevinin hesap işlerine ait talimat)

${ }^{65} B C A, 030.10 / 117.817 .21$ (Londra Halkevi'nin mevcut durumu hakkında CHP Genel Sekreterliği'nin 13.11.1946 tarihli raporu) 
Londra Halkevi'nin gelirlerini; CHP Genel Sekreterliği ve British Council'den yapılan yardımlar, üye aidatları, bağışlar ve kira gelirleri oluşturmaktadır. Halkevinin gelirleri arasına 1947 yılından itibaren kitap satışından elde edilen gelirler de eklenmiştir ${ }^{66}$. Halkevinin giderleri arasında ise personel maaşı, idari masraflar, kira ve tadilat giderleri ve benzeri harcamalar yer almaktadir ${ }^{67}$.

British Council tarafindan halkevine yapılan yardımlar 1944'ten sonra son bulmuştur ${ }^{68}$. Ayrıca, halkevinin gelirleri arasında en fazla payı CHP Genel Sekreterliği'nden yapılan yardımlar oluşturmakla birlikte, halkevinin büyük ölçüde işlevini yitirdiği 1947 yılından itibaren bu kuruluşa artık CHP Genel Sekreterliği'nden de para gönderilmediği anlaşılmaktadır ${ }^{69}$. CHP'nin halkevine yaptığı yardımları kesmesinde Londra Halkevi'nin mevcut durumuyla ilgili olarak 1947 yılında hazırlanan raporda; bu kuruluşun giderlerinin CHP Genel Sekreterliği tarafından karşılanmasında yaşanan sıkıntı nedeniyle yardımların bizzat hükümet tarafından karşılanması gerektiğinin bildirilmesi de $\mathrm{d}^{70}$ etkili olmuştur. Ayrıca çok partili hayata geçilmesinin ardından, DP milletvekillerinin halkevlerinin birer kültür kurumu olmaktan çıkıp CHP'nin siyasi birer organı olduklarını iddia etmesi ve bu nedenle de bütçeye halkevleri adına konulacak paraya itiraz etmeleri ${ }^{71}$ nedeniyle halkevleri en önemli gelir kaleminden önemli ölçüde mahrum kalmıştır. Türkiye' deki halkevlerinin faaliyetlerini durdurmasında başlıca etkenlerden biri faaliyetleri gerçekleştirecek gelirden yoksun bırakılmaları sayılabilirken, Londra Halkevi'nin işlevini yitirmesinde bu sorun çok fazla etkili olmamışır ${ }^{72}$.

\section{d. Londra Halkevi’nin Üyeleri}

Londra Halkevi açıldığında Türk vatandaşı olmayanların halkevine üye olmalarına müsaade edilmezken, İngilizlerden gelen istek üzerine Londra Halkevi Başkanı Rauf Orbay'ın 11 Haziran 1942 tarihli teklifinden sonra cetveli)

${ }^{66} \boldsymbol{B C A}, 490.01 / 1065.1087 .1$ (Londra Halkevi'nin 1947 yılı kati hesap bilânçosu)

BCA, 490.01/1065.1087.1; BCA, 490.01/1065.1086.1 (Londra Halkevi gelir-gider 687 sterlindir. Bkz. BCA, 490.01/1065.1087.1 (Londra Halkevi'nin gelir-gider tablosu)

${ }^{69} \boldsymbol{B C A}, 490.01 / 1066.1088 .1$ (Dişişleri Bakanlığı'ndan 22.8.1950 tarihinde CHP Genel Sekreterliği'ne yazılan yazı)

70 BCA, 03.10/117.817.20 (Kasım 1946 tarihinde Londra Halkevi'nin mevcut durumuyla ilgili Başbakan Recep Peker'e sunulan inceleme raporu)

${ }_{71}$ T.B.M.M. Tutanak Dergisi, C.9, Dönem IX, Toplantı 1, T.B.M.M. Basımevi, Ankara 1951, s.610; "Bütçe Görüşmeleri Dolayısıyla B.M. Meclisi'nde Halkevleri Hakkında Konusulanlar", $\ddot{\boldsymbol{U}} \boldsymbol{l k} \boldsymbol{k} \ddot{\boldsymbol{u}}, \mathrm{C} .3, \mathrm{~S} .27$, Mart 1949, s.2-3.

${ }^{2}$ Londra Halkevi'nin faaliyetlerini durdurması ve nasıl ıslah edilebileceğine ilişkin raporlarda halkevinin işlevini yitirmesinde maddi sıkıntıların önemli bir yerinin bulunmadığı, halkevi bütçesinde para olmasına karşın bunun sağlıklı bir şekilde harcanmadı̆̆ Bkz: $\boldsymbol{B C A}, 490.01 / 1065.1086 .1$ (Emin Hekimgil'in Londra Halkevi'nin durumuyla ilgili Cumhuriyet Halk Partisi Genel Sekreterliği'ne 21.9.1948 tarihinde sunduğu rapor) 
yönetmeliğe, İngiliz vatandaşlarının da fahri üye olarak kabul edilebileceği maddesi ilave edilmiştir ${ }^{73}$. İngilizlerin de üyeliğe kabulünün karar altına alınmasını takip eden 7 aylık sürede, 230 İngiliz'in halkevine üye olmas ${ }^{74}$ İngilizlerin bu kuruluşa gösterdiği yakın ilginin bir göstergesidir. Halkevi'nin yabancı uyruklu üyeleri arasında çok az sayıda olmakla birlikte Rum, Ermeni ve Musevi de bulunmaktadır ${ }^{75}$. Londra Halkevi'nin üyeleri arasında toplumun farklı kesimlerinden insanların bulunmasının yanında bazı İngiliz devlet adamlarının da halkevine üye olmuşlardır. Örneğin 1943 yılının Ocak ayında İngiliz Dışişleri Bakanı Anthony Eden ve eşi ile birlikte bazı devlet adamları da halkevine üye olmaları dikkati çekmektedir ${ }^{76}$.

1944 yılına gelindiğinde halkevine üye olan İngilizlerin sayısı 300'e yükselmiş ve bu üyeler halkevini düzenli olarak ziyaret ederek faaliyetlere iştirak etmişledir. Ayrıca Türk üyeler ile İngiliz üyeler arasında sıkı dostluk ilişkileri kurulmaya başlamıştır ${ }^{77}$.

Halkevinin büyük ölçüde işlevini yitirdiği 1947 yılında üye sayısı 315 olmakla birlikte, bu üyelerden ancak 193'ü halkeviyle ilişkilerini sürdürmüş ve aidatlarını düzenli olarak vermiştir. Birçok üyenin halkeviyle irtibatını kesmesine, halkevinin 1945 yılından sonra hemen hemen hiçbir etkinlik gösterememesi sebep olmuştur ${ }^{78}$. Londra'da bulunan Türk vatandaşlarının 50 civarında öğrenci ile çok az sayıda, subay ve tüccardan oluştuğ ${ }^{79}$ dikkate alınırsa halkevi üyelerinin büyük çoğunluğunun İngilizlerden oluştuğu kendiliğinden ortaya çıkmaktadır.

\section{Londra Halkevi'nde Gerçekleştirilen Faaliyetler}

Türkiye'de açılmış olan bütün halkevleri ve halkodaları, faaliyetlerini CHP tarafından hazırlanan ve yayımlanan "CHP Halkevleri Çalışma Talimatnamesi”nde belirtilen esaslar üzerine her birinin ayrı bir faaliyet

${ }^{73} B C A, 490.01 / 1065.1086 .1$ (Rauf Orbay tarafından 27.8.1942 tarihinde CHP Genel Sekreterliği'ne gönderilen yazı)

${ }^{74}$ BCA, 490.01/1064.1083.3 (Londra Büyükelçiliği tarafından 28.1.1944 tarihinde CHP Genel Sekreterliği'ne sunulan halkevinin ilk bir yıllık faaliyet raporu)

${ }^{75}$ BCA, 490.01/1065.1086.1 (CHP Maraş Milletvekili Hasan Reşit Tankut'un Londra Halkevi'nin mevcut durumuyla ilgili 27.8.1948 tarihinde CHP Genel Sekreterliği'ne gönderdiği rapor)

${ }_{76}$ BCA, 490.01/1064.1083.3 (Londra Büyükelçisi tarafından 5.2.1943 tarihinde CHP Genel Sekreterliği'ne sunulan halkevinin 1943 yılı Ocak ayı faaliyet raporu); BCA, 490.01/1064.1083.3 (Londra Büyükelçiliği tarafından 28.12.1944 tarihinde CHP Genel Sekreterliği'ne sunulan halkevinin ilk bir yıllık faaliyet raporu)

${ }^{77} B C A, 490.01 / 1065.1086 .1$ (Londra Halkevi İstişare Komitesi tarafından 1945'de CHP Genel Sekreterliği'ne sunulan 3. Senelik rapor)

${ }^{78} B C A, 490.01 / 1065.1086 .1$ (Londra Halkevi Başkanlığ tarafından 1.7.1947 tarihinde CHP Genel Sekreterliği'ne sunulan idare heyeti raporu)

${ }^{79} B C A, 490.01 / 1065.1086 .1$ (CHP Maras Milletvekili Hasan Reşit Tankut'un Londra Halkevi'nin mevcut durumuyla ilgili 27.8.1948 tarihinde CHP Genel Sekreterliği'ne gönderdiği rapor); ayrıca bkz: $B C A$, 490.01/1066.1088.1 (CHP V. Büro Şefliğinden CHP Genel Sekreterliği' 'ne gönderilen tarihsiz yazı) 
sahası olan dokuz ayrı şube bünyesinde gerçekleştirirken; Londra Halkevi, taşıdığı özel koşullar gereğince söz konusu talimatnameye tabi tutulmamiştır.

Londra Halkevi'nde gerçekleştirilecek olan faaliyetler düzenli bir program dairesinde gerçekleştirilmemekle birlikte, özellikle açılışı takip eden ilk birkaç yıllık sürede halkevinin yönetim kurulu tarafından aylık faaliyet programlarının hazırlandığ 1 görülmektedir ${ }^{80}$. Londra Halkevi'nin faaliyetleri, Türkiye'de bulunan halkevleri gibi çeşitlilik arz etmeyip daha çok halkevinin kuruluş amaçları doğrultusunda; Türkçe kursları, konferanslar, sergiler, çay, balo vb. etkinliklere yoğunlaştırılmıştır. Londra Halkevi Başkanlığı tarafından CHP Genel Sekreterliği'ne gönderilen aylık ve yıllık faaliyet raporları ile teftiş raporları incelendiğinde halkevinin açılışını takip eden ilk üç yılda oldukça faal olduğunu, 1945 yılından itibaren ise işlevini yitirdiği görülmektedir. Londra Halkevi tarafından gerçekleştirilen faaliyetlere başlıklar halinde değinecek olursak:

\section{a. Türkçe ve İngilizce Kursları}

Londra Halkevi tarafından en istikrarlı ve düzenli olarak sürdürülen faaliyet, halkevi bünyesinde açılan Türkçe ve İngilizce kursları olmuştur. Halkevinin açılışında, bina temininde ve halkevi giderlerinin bir kısmının karşılanmasına önemli katkıları olan British Council'in halkevi ile ilişkilerini sürdürmek için halkevinde Türkçe dersleri verilmesini şart koşması, bu kursların açılmasında önemli ölçüde etkili olmuş ve halkevinin açılışından kısa süre sonra Türkçe derslerine başlanmıştır. Halkevinde verilen Türkçe derslerin yanı sıra özellikle Londra'da bulunan ve İngilizcesi iyi olmayan Türk öğrencilere de British Council tarafından temin edilen öğretmenler vasitasıyla İngilizce dersleri verilmiştir ${ }^{81}$.

Londra Halkevi'nde verilen Türkçe kursları, yeni başlayanlar ve orta düzeyde olanlar olmak üzere iki ayrı kur halinde verilmiştir. Temmuz 1942 tarihi itibariyle başlangıç seviyesinde 40, orta seviyede ise 5 kursiyer Türkçe kurslarına devam ederken, İngilizce kurslarına ise Türkiye'den Londra'ya öğrenim için giden 20 denizcilik bölümü öğrencisi devam etmiştir ${ }^{82}$. Bir yandan halkevinde düzenlenen Türkçe kursunda başarı gösterenler mezun edilirken, diğer taraftan yeni kurslar açılmıştır. 1943 yılının şubat ayında mevcut Türkçe kurslarına yenisi eklenmiş ve kursiyer sayısı 50'ye

${ }^{80}$ Londra Halkevi İdare Kurulu tarafından oluşturulan aylık faaliyet programları hakkında bkz: $\boldsymbol{B C A}, 490.01 / 1064.1083 .3$ (Londra Halkevi'nin faaliyet raporları ile ilgili yazışmalar)

${ }^{81} \boldsymbol{B C A}, 490.01 / 1065.1087 .1$ (Londra Büyükelçisi H. Rauf Orbay tarafından 16.10.1942 tarihinde CHP Genel Sekreterliği'ne gönderilen yazı)

${ }^{82}$ BCA, 490.01/1064.1083.3 (Londra Halkevi Başkanlığı'nın CHP Genel Sekreterliği'ne gönderdiği 21.7.1942 tarihli yazı) 
ulaşmıştır ${ }^{83}$. Türkçe kursları halkevi kâtibi tarafından her sınıfa haftada iki saat olarak verilirken, İngiliz öğretmenler tarafından Türk vatandaşlarına verilen İngilizce kursları da sürdürülmüştür ${ }^{84}$.

1944 yılına gelindiğinde ise kursiyerlerden ileri seviyeye geçenler için Türkçe konuşma sınıfı açılması kararlaştırılmıştır ${ }^{85}$. 1945 ve 1946 yılları arasında Türkçe kurslarının öğrenci sayılarında önceki yıllara göre bir azalma olmuştur. Bu azalmanın sebebi Halkevi Başkanı Ruşen Eşref Ünaydın tarafından II. Dünya Savaşı'nın getirdiği ağır şartlara bağlanmıştır. Halkevinde devam eden kurslar için Türkiye'den Türkçe okuma ve gramer kitapları ile sözlükler talep edilmiştii ${ }^{86}$.

Londra Halkevi'nin önemli ölçüde işlevini yitirdiği ve faaliyetlerin durma noktasına geldiği 1948 yılında dahi Türkçe kurslarının devam ettiriliyor olmas ${ }^{87}$ bu kurslara olan ilginin göstergelerindendir. Uzun süre Halkevi Kâtibi Ali Rıza Şencan tarafından verilen Türkçe kursları sayesinde pek çok İngiliz Türkçe öğrenmiş ve halkevinin fahri üyeleri olarak faaliyet göstermiştir. Halkevinde düzenlenen Türkçe kurslarına katılan İngiliz Yazar Margery Kent'in "Fairy Tales From Turkey" adlı eserini kendisine ilk Türkçe dersini veren Halkevi Kâtibi Ali Rıza Şencan'a şükranla ithaf etmesi $^{88}$ Londra Halkevi'nde düzenlenen Türkçe kurslarına duyulan memnuniyetin bir göstergesidir.

\section{b. Konferanslar}

Londra Halkevi'nin Türk kültürünü ve "Çağdaş Türkiye'yi” her yönüyle İngilizlere tanıtmak ve iki ülke arasındaki kültürel ilişkileri kuvvetlendirmek adına gerçekleştirdiği faaliyetlerin başında halkevinde düzenlenen konferanslar gelmektedir. Londra Halkevi'nde düzenlenen konferanslar diğer faaliyetlerde olduğu gibi halkevinin açılışını takip eden ilk üç yılda yoğun olarak gerçekleştirilmiş, 1946 yılından sonra ise büyük oranda terk edilmiştir.

${ }^{83}$ BCA, 490.01/1064.1083.3 (Londra Büyükelçisi tarafından 5.2.1943 tarihinde CHP Genel Sekreterliği'ne sunulan halkevinin 1943 yilı Ocak ayı faaliyet raporu)

${ }_{84} B C A, 490.01 / 1064.1083 .3$ (Londra Halkevi Başkanlığ 1 tarafından 28.1.1944 tarihinde CHP Genel Sekreterliği'ne sunulan yıllık faaliyet raporu)

${ }_{85} B C A, 490.01 / 1065.1086 .1$ (Londra Halkevi İstişare Komitesi tarafından Şubat 1945 'de CHP Genel Sekreterliği'ne sunulan 3. Senelik rapor); $B C A, 490.01 / 1065.1086 .1$ (CHP Kars Milletvekili Tezer Taşkıran'ın 3.12. 1946 tarihinde CHP Genel Sekreterliği'ne sunduğg rapor)

${ }_{86}$ BCA, 490.01/1065.1086.1 (Londra Halkevi Başkanı Ruşen Eşref Ünaydın'ın 27.03.1945 tarihinde CHP Genel Sekreterliği'ne halkevinin mevcut durumu ile ilgili sunduğu rapor)

${ }_{87}$ BCA, 490.01/1065.1086.1 (CHP Maraş Milletvekili Hasan Reşit Tankut'un halkevinin mevcut durumuyla ilgili 27.8.1948 tarihinde CHP Genel Sekreterliği'ne gönderdiği rapor)

${ }^{88}$ Bkz: Margery Kent, Fairy Tales From Turkey, London 1960, s.i. 
Halkevinin açılışından hemen sonra başlatılan konferanslar belirli bir program dairesinde gerçekleştirilmiştir. Örneğin 1942 yılında hazırlanan faaliyet programında; her ay bir konuşmacı tarafından Türkiye'deki sosyal ve kültürel yapı üzerine bir konferans verilmesi ve bu konferanslara Londra'da bulunan çeşitli meslek gruplarından insanların ve farklı okullardan öğretmen ve öğrencilerin de davet edilmesi kararlaştırılmıştır ${ }^{89}$.

1942 yılında büyük ölçüde bu programa uyulmuş ve halkevinin açılışını takip eden ilk on dört ayda 15 konferans verilmiştir. Konferans verenler arasında; Suphi Bekan, Ali Rıza Şencan gibi Türklerin yanı sıra Sir Wyndham Deeds, Sir Percy Loraine, Major Talbot Rice, Miss Winifred Lamb ve Profesör Baxter gibi İngilizler de bulunmaktadır ${ }^{90}$. Bu yıl içerisinde verilen konferansların bazılarının konuları "Halıcılık ve Dokuma", "İstanbul ve Ankara", "Karagöz ve Ortaoyunu" olmuştur. Bu konferanslardan geleneksel Türk tiyatrosunu İngilizlere tanıtmak amacıyla gerçekleştirilen "Ortaoyunu ve Karagöz" konulu konferanslara ardından karagöz sahnelenmiştir. Doksan kişinin katıldığı bu program çok beğenilmiş ve tekrarı istenmiştir ${ }^{91}$.

1942 yılında halkevinde verilen konferanslara katılan İngilizlerin özellikle Türkiye'deki eğitim usulleri, köy hayatı ve Türk kadınının mevcut durumu hakkında sorular sormalarına rağmen, halkevi yöneticileri bu soruları gerektiği gibi cevaplayacak yeterli bilgiye sahip olmadıkları için ${ }^{92}$ dinleyicileri yeterince aydınlatamamışlardır.

Halkevi tarafından verilen konferanslara 1943 yılında da devam edilmiştir. Bu yıl içerisinde verilen konferanslardan bazıları: British Council Başkanı Sir Malcolm Robertson tarafından verilen"Son Türkiye Ziyaretim" konulu konferans ve Halkevi Kâtibi Ali Rıza Şencan tarafından verilen “Türkiye'nin Belli Başlı Abideleri” konulu konferanstır" ${ }^{93}$. Bu konferansların yanı sira Sir Wyndham Deeds, Lady Govers, Miss Fripp ${ }^{94}$ ve Mrs. Rowntree $^{95}$ tarafından çeşitli konularda konferanslar verilmiştir. Halkevinde verilen bu konferansların ilave olarak kalabalık gruplar halinde halkevine

${ }^{89}$ BCA, 490.01/1064.1083.3 (Londra Halkevi Başkanlığı'nın CHP Genel Sekreterliği'ne gönderdiği 21.7.1942 tarihli yazı)

${ }^{90}$ BCA, 490.01/1064.1083.3 (Londra Büyükelçiliği tarafından 28.1.1944 tarihinde CHP Genel Sekreterliği'ne sunulan halkevinin ilk bir yıllık faaliyet raporu)

91 BCA, 490.01/1064.1083.3 (Londra Büyükelçiliği'nden 11.1.1943 tarihinde CHP Genel Sekreterliği'ne sunulan halkevinin Aralık 1942 faaliyet raporu)

${ }_{92}$ BCA, 490.01/1064.1083.3 (Londra Büyükelçiliği tarafından 28.1.1944 tarihinde CHP Genel Sekreterliği'ne sunulan halkevinin ilk bir yıllık faaliyet raporu)

${ }_{93} B C A, 490.01 / 1064.1083 .3$ (Londra Büyükelçisi tarafından 18.9.1943 tarihinde CHP Genel Sekreterliği'ne sunulan halkevinin Temmuz 1943 faaliyet raporu)

${ }_{94}$ BCA, 490.01/1064.1083.3 (Londra Büyükelçisi tarafından 29.3.1943 tarihinde CHP Genel Sekreterliği'ne sunulan halkevinin Mart 1943 faaliyet raporu)

${ }^{95} B C A, 490.01 / 1064.1083 .3$ (Londra Büyükelçisi tarafından 24.4.1943 tarihinde CHP Genel Sekreterliği'ne sunulan halkevinin Nisan 1943 faaliyet raporu) 
ziyaretçiler geldiğinde çeşitli açılardan Türkiye'yi tanıtmaya yönelik konuşmalar da yapılmıştır.

Londra Halkevi'nde verilmekte olan aylık konferanslara 1944 yılında da devam edilmiş ve İngiltere'ye gelen üç Türk vatandaşı doktor tarafından çeşitli konularda konferanslar verilmiştir. Cambridge'de öğrenci olan Yıldız Sertel tarafından "Yeni Türkiye'de Kadın”, Ruşen Eşref Ünaydın tarafından verilen "Türk Edebiyatı", Mr. Steagman tarafından verilen "Bugünkü Türk Ressamları" konulu konferans, bu yıl içinde gerçekleştirilen önemli etkinliklerdendir. Bunların dışında halkevinde konferans veren İngiliz konferansçılar şunlardır: Miss Ann Bridge, Sir Wyndham Deeds, Mr. C.T.S. Lake, Mr. John Steegman, Sir Ronald Storrs. 1944 yılında gerçekleştirilen bu konferanslara katılım oldukça yoğun olmuştur ${ }^{96}$.

1944 yılında aylık düzenlenen konferansların yanı sıra İngilizlerden gelen talep üzerine Nisan ayında Türkiye hakkında geniş katılımlı sohbetler düzenlenmiştir. Soru-cevap şeklinde yapılan bu sohbetlerde, Türkiye ve Türk kültürüne ilişkin pek çok konuya değinilmiştir. Yine aynı yıl içerisinde, Türk atasözleri ve bunlara karşıllk bulmak için halkevinde bir toplantı düzenlenmiş ve Türkçe atasözlerine İngilizce karşılıklar bulunmaya çalışılmıştır ${ }^{97}$.

Halkevinde düzenlenen konferanslara İngilizler tarafından büyük ilgi gösterilmesi sebebiyle, konferansları daha faydalı hale getirebilmek için çeşitli teşebbüslerde bulunulmuştur. Örneğin Londra Büyükelçisi ve Halkevi Başkanı Ruşen Eşref Ünaydın tarafından 27 Mart 1945 tarihinde CHP Genel Sekreterliği'ne gönderilen bir yazıda; halkevinde verilen konferansların düzenli bir program çerçevesinde ve bilimsel nitelikte olması gerektiği ifade edildikten sonra hangi konularda konferanslar verilirse daha faydalı olacağına ilişkin bir liste sunulmuştur. Söz konusu listede; Atatürk ilkeleri, Türk anayasası ve idare şekli, Türkiye'nin sağlık, eğitim işleri ve kurumları, Türkiye'de kadın hayatı ve cemiyetleri, tarım, ziraat, hayvancılık, madencilik, turizm vb. konular yer almıştır. Ünaydın, yine aynı yazısında konferansların Türk profesörler ya da alanında uzman kişiler tarafından verilmesi gerektiğini, örneğin her yıl 10-12 konferansçının belirlenerek bunların üçer dörder konferans vermesi durumunda bunun İngiltere'de bulunan üniversite, sanayi ve ticaret çevrelerinde büyük yankı uyandıracağını belirtmiştir. Bunun yapılamaması halinde, en azından Londra'ya özenle hazırlanmış konferans metinlerinin gönderilmesinin dahi önemli tesir yapacağını ifade eden Ünaydın, Türk konferansçılarının yanı

\footnotetext{
${ }^{96} B C A, 490.01 / 1065.1086 .1$ (Londra Halkevi İstişare Komitesi tarafından Şubat 1945 'de CHP Genel Sekreterliği'ne sunulan 3. Senelik rapor)

${ }_{97} B C A, 490.01 / 1065.1086 .1$ (Londra Halkevi İstişare Komitesi tarafından Şubat 1945 'de CHP Genel Sekreterliği'ne sunulan 3. Senelik rapor)
} 
sıra Türkiye'yi tanıyıp seven İngilizlere de konferans verdirmenin faydalı olacağını ifade etmiştir ${ }^{98}$.

Ruşen Eşref Ünaydın'ın bu öneri ve isteklerini karşılayabilmek amacıyla CHP Genel Sekreteri N. Kansu tarafından Dışişleri Bakanı Hasan Saka'ya 5 Aralık 1945 tarihli yazılan bir yazıda; çeşitli sebeplerle Londra'ya gidecek olan Türk vatandaşlarına konferanslar verdirilmek istendiğini, bu nedenle ilgili şahısların kimlik ve meslek bilgilerinin devamlı surette bildirilmesini istemiştir ${ }^{99}$.

Halkevinde verilen konferansların sayı ve niteliğini artırmaya yönelik bu çabalar sonuç vermemiş ve 1946 yılından itibaren halkevinin işlevini yitirmesine paralel olarak konferanslara da son verilmiştir.

\section{c. Sinema}

Günümüzde en önemli kitle iletişim araçlarından biri olan sinema, hem görsel hem de işitsel olması sebebiyle büyük bir etki alanına sahiptir. Sinema, 1940'lı yıllarda da önemli bir propaganda aracı olarak kullanılmıştır. Sinemanın geniş kitleleri etkileme özelliğinden istifade etmek isteyen Londra Halkevi yöneticilerinin de Türkiye'yi ve Türk kültürünü İngilizlere tanıtmak için kullandı $\breve{g}_{1}$ başlıca araçlardan biri, halkevinde gösterime sunulan belgesel nitelikli filmlerdir. 1942 yılından itibaren halkevinin düzenlediği hemen hemen her etkinlikte Türkiye'yi tanıtmaya yönelik filmler gösterilmiştir.

1942 yılında halkevinde mevcut olan filmlerin konusunu daha çok İstanbul'da bulunan tarihi eserler, Ankara'da bulunan ve "Çağdaş Türkiye"yi simgeleyen kurum ve kuruluşlar, Türkiye'deki bayram kutlamaları, Atatürk ve İsmet İnönü'yü anlatan filmler, Türkiye'nin tarımsal faaliyetleri ve ürünleri vb. konulu belgeseller oluşturmuştur. Halkevinde bulunan bu belgesel filmleri yetersiz gören Londra Halkevi Başkanlığ 1,21 Temmuz 1942 tarihinde CHP Genel Sekreterliği'ne yazdığı bir yazıyla; Türkiye'deki askeri ve sivil okullar, fabrikalar, balıkçılık, halıcılık, çinicilik, halkevlerinin faaliyetleri, köy ve köy hayatı, spor hareketleri, halk oyunları ve milli kıyafetler, doğal güzellikler ve her türlü tarım ürünü gibi Türkiye'nin sosyal, kültürel, iktisadi, askeri ve her alandaki ilerleyiş ve yükselişi ile ilgili aydınlatıcı bilgi veren filmler talep etmiştir.

1942 yılında hazırlanan faaliyet programında da her on beş günde bir Londra'da bulunan çeşitli meslek gruplarından insanların ve öğrencilerin

98 BCA, 490.01/1065.1086.1 (Londra Halkevi Başkanı Ruşen Eşref Ünaydın'ın 27.03.1945 tarihinde CHP Genel Sekreterliği'ne halkevinin mevcut durumu ile ilgili sunduğu rapor)

${ }^{99}$ BCA, 490.01/1065.1086.1; (CHP Genel Sekreteri ve Kırklareli Milletvekili N. Kansu tarafından 5.12.1945 tarihinde Londra Halkevi Başkanlığı'na gönderilen yazı) 
halkevine davet edilerek, bu insanlara Türkiye hakkında aydınlatıcı filmler izlettirilmesi kararlaştırılmıştır ${ }^{100}$. Alınan bu karar uyarınca özellikle kalabalık gruplar halinde halkevini ziyaret eden İngilizlere belgesel film gösteriminde bulunulmuştur.

1945 yılına gelindiğinde Londra Halkevi'nde, CHP Genel Sekreterliği'nden gönderilen 17 Türkçe film ile British Council'den temin edilen 62 İngilizce film bulunmakla birlikte, bu filmler yeterli görülmeyerek CHP Genel Sekreterliği'nden yeni film talebinde bulunulmuştur ${ }^{101}$.

Açılışı takip eden ilk üç yıllık dönemde Türkiye'yi tanıtmak için sinemadan oldukça etkin bir biçimde istifade eden Londra Halkevi, 1945 yılından sonra tıpkı diğer faaliyetlerde olduğu gibi bu faaliyetini de sonlandırmıştır.

\section{d. Sergi}

Londra Halkevi'nin bir diğer faaliyet alanını da halkevinde geçici ve daimi surette açılan sergiler oluşturmaktadır. Halkevinin açılışından kısa süre sonra oluşturulan fotoğraf sergilerinde daha çok Türkiye'deki sanayi, ziraat, eğitim, güzel sanatlar, spor ve diğer sahalardaki gelişmeleri gösteren fotoğraflar sergilenmiştirr ${ }^{102}$. Türkiye'nin şehir ve kır hayatına ilişkin fotoğrafların da yer aldığı bu sergiler halkevini ziyarete gelen her gruba gezdirilmiş ve fotoğrafların mahiyeti hakkında bilgiler verilmiştir ${ }^{103}$. Bunun yanı sıra Türkiye'deki çeşitli işletmelere ilişkin maketler de halkevinde sergilenmiştir ${ }^{104}$

Londra Halkevi'nde açılan sergilerden en fazla beğenileni ve ses getireni 1943 yılında düzenlenen resim sergisi olmuştur. Söz konusu sergideki resimler, 1940 yılında Yozgat Ortaokulu öğrencileri tarafından yapılmış olup İstanbul ve Ankara'da da sergilenmiştir. 1943 yılına gelindiğinde British Council'in vasıtasıyla Londra'ya getirilen bu resimler, Londra Halkevi’nde sergilenmeye başlanmıştır ${ }^{105}$. Serginin açıllış

${ }^{100}$ B C A , 490.01/1064.1083.3 (Londra Halkevi Başkanlı̆̆g'ndan CHP Genel Sekreterliği'ne gönderilen 21.7.1942 tarihli yazı)

101 BCA, 490.01/1065.1086.1 (Londra Halkevi Başkanı Ruşen Eşref Ünaydın'ın 27.03.1945 tarihinde CHP Genel Sekreterliği'ne halkevinin mevcut durumu ile ilgili sunduğu rapor)

${ }^{102}$ BCA, 490.01/1066.1088.1 (Londra Büyükelçisi H. Rauf Orbay tarafından 11.6.1942 tarihinde CHP Genel Sekreterliği'ne gönderilen yazı)

${ }^{103} B C A, 490.01 / 1064.1083 .3$ (Londra Büyükelçiliği tarafından 31.5.1943 tarihinde CHP Genel Sekreterliği'ne sunulan halkevinin Mayıs 1943 faaliyet raporu)

${ }^{104} B C A, 490.01 / 1065.1086 .1$ (CHP Genel Sekreteri ve Kirklareli Milletvekili N. Kansu tarafından 11.2.1946 yılında Başbakan Şükrü Saraçoğlu'na sunulan rapor)

${ }^{105}$ BCA, 490.01/1064.1083.3 (Londra Büyükelçiliği tarafından 28.1.1944 tarihinde CHP Genel Sekreterliği'ne sunulan halkevinin ilk bir yıllık faaliyet raporu); $B C A$, 490.01/1064.1083.3 (Londra Büyükelçiliği tarafından 16.6.1943 tarihinde CHP Genel Sekreterliği'ne gönderilen Mayıs 1943 faaliyet raporu) 
konuşmasını yapan Edinburg Üniversitesi Güzel Sanatlar Tarihi Profesörü Harbert Read, resimleri çizen çocuklar ve öğretmenlerinden övgüyle bahsetmiştir ${ }^{106}$. Söz konusu resimler bir ay boyunca halkevinde sergilenmiştir ${ }^{107}$.

Londra Halkevi'nin 5 Nisan 1950 tarihinde Londra Büyükelçiliği'ne devri sırasında hazırlanan tutanaktan halkevinde bir el işleri sergisi düzenlendiği ve bunun için 17 parça camekân oluşturulduğu anlaşılmaktadır $^{108}$.

\section{e. Bayram Kutlamalart}

Londra Halkevi'nin bir başka etkinlik alanı da millî bayramların coşku içerisinde kutlanarak bu bayramlara dayanak noktası olan gelişmeler hakkında İngilizleri bilgilendirmektir. Londra Halkevi'nde kutlanan her millî bayramın ruhuna uygun faaliyetler gerçekleştirilmeye çalışılmıştır. Örneğin 1942 yılında Ulusal Egemenlik ve Çocuk Bayramı kutlamaları çerçevesinde halkevinde düzenlenen programa 400 çocuk davet edilmiştir. Yine aynı yılın 19 Mayıs Gençlik ve Spor Bayramı kutlamaları kapsamında da bir grup sporcu halkevine davet edilmiştir. Milli bayramlarda halkevinde düzenlenen etkinliklere davet edilenlere günün anlam ve önemini belirten konuşmalar yapılmış, çay ziyafeti verilmiş ve Türkiye ile ilgili belgesel filmler izlettirilmiştir ${ }^{109}$. Halkevinde 1942 yılında gerçekleştirilen Cumhuriyet Bayramı kutlama merasimlerine İngilizlerin yanı sıra Londra da yaşayan Türk vatandaşları da davet edilmiş ve onlara da çay ziyafeti verilmiştir ${ }^{110}$.

Londra Halkevi tarafından 1944 yılında da milli bayramlarda çeşitli etkinlikler düzenlenmiştir. Bu yılın 23 Nisan Ulusal Egemenlik ve Çocuk Bayramı münasebetiyle St. Marylebone Kasabası çocukları halkevine davet edilerek bir çay ziyafeti verilmiş ve film gösteriminde bulunulmuştur. Yine aynı yılın19 Mayıs Gençlik ve Spor Bayramı'nda Londra Büyükelçisi tarafından halkevinde bir kabul merasimi düzenlenmiş ve bu merasime halkevinin bütün üyeleri davet edilmiştir. 29 Ekim Cumhuriyet Bayramı'nda ise 170 kişinin katılımıyla bir çay ziyafeti düzenlenmiştir ${ }^{111}$.

${ }^{106}$ Vedat Nedim Tör, Ylllar Böyle Geçti, Milliyet Yayınları, 1976, s.82-85.

${ }^{107}$ BCA, 490.01/1064.1083.3 (Londra Büyükelçiliği tarafından 7.7.1943 tarihinde CHP Genel Sekreterliği'ne sunulan halkevinin Haziran 1943 faaliyet raporu)

${ }^{108} B C A, 490.01 / 1066.1088 .1$ (Dişişleri bakanlığından 22.8.1950 tarihinde CHP Genel Sekreterliği'ne yazılan yazı)

${ }^{109} B C A$, 490.01/1064.1083.3 (Londra Büyükelçiliği tarafından 28.1.1944 tarihinde CHP Genel Sekreterliği'ne sunulan halkevinin ilk bir yıllık faaliyet raporu)

${ }^{10}$ Milli bayramların kutlanılmasında Londra Halkevi'nin gerçekleştirdiği faaliyetlere ilişkin olarak bkz: $B C A, 490.01 / 1064.1083 .3$ (Londra Halkevi'nin faaliyet raporları ile ilgili yazışmalar)

$111 B C A, 490.01 / 1065.1086 .1$ (Londra Halkevi İstişare Komitesi tarafından Şubat 1945 'de CHP Genel Sekreterliği'ne sunulan 3. Senelik rapor) 
Milli bayramların yanı sıra, Türkiye'deki halkevlerinin açılış tarihi olan 19 Şubat'ta hem yeni halkevlerinin açılıșı hem de halkevlerinin kuruluşlarının yıldönümleri her yıl büyük coşku içerisinde, çeşitli etkinliklerle kutlanmıştır. Bu kapsamda, Londra Halkevi'nin kuruluşunun birinci yıldönümü olan 19 Şubat 1943 tarihinde, Londra Büyükelçiliği tarafından halkevi binasında bir davet verilmiştir. Söz konusu davete; Mısır, İran, Irak, Afgan elçileriyle Hindistan Fevkalade Komiseri ve Türk elçilik ve konsolosluğundan kırk kişilik bir grup davet edilmiştir ${ }^{112}$.

\section{Etkinlikler}

f. Halkevine Gerçekleştirilen Ziyaretler ve Çay, Balo, Davet vb.

Londra Halkevi'nde en sık ve en istikrarlı olarak düzenlenen etkinliklerin başında çay ziyafeti, balo, davet ve benzeri etkinlikler gelmektedir. Söz konusu etkinlikler tıpkı diğer faaliyet alanlarında olduğu gibi, özellikle halkevinin açılışını takip eden üç yıllık sürede gerçekleştirilmiştir. Londra Halkevi'nde düzenlenen çay ziyafeti ve davet gibi etkinlikler daha çok, kalabalık gruplar halinde halkevini ziyaret etmek isteyen ya da halkevi başkanlığı tarafından davetiye gönderilen çeşitli kamu kuruluşu, sivil toplum örgütü mensupları ve çeşitli kademelerdeki okullara ait öğretmen ve öğrenciler; çeşitli vesilelerle Londra'da ikamet eden Türk vatandaşları ile kısa süreliğine Türkiye'den Londra'ya gelen gruplar için düzenlenmiştir. $\mathrm{Bu}$ tür etkinliklerin hemen hepsinde ziyaretçi ya da davetlilere bir çay ziyafeti verildikten sonra, Türkiye'yi ve Türk kültürünü tanıtmaya yönelik konuşmalar yapılmış, bundan sonra ise halkevinde sürekli olarak açık tutulan sergiler gezdirilmiş ve Türkiye ile ilgili çeşitli belgesel filmler izlettirilmiştir ${ }^{113}$.

Londra Halkevi'nin ilk faaliyet yılı olan 1942'de halkevini yüzlerce kişi ziyaret etmiştir. Bu yılın Haziran ayında 85 İngiliz'in yanı sıra eğitim amaciyla Londra'da bulunan 41 Türk hava subayı da halkevini ziyaret edenler arasındadır ${ }^{114}$. Yine 1942 yılının Temmuz ve Ağustos aylarında Londra'da bulunan çeşitli okullara mensup öğretmen ve öğrencilerin yanı sıra ${ }^{115}$ Türk hava subayları da halkevine davet edilerek onurlarına çay ziyafeti verilmiştir. Bu yılın Eylül ayında ise, Tük Milletvekilleri ve

${ }^{112}$ BCA, 490.01/1064.1083.3 (Londra Büyükelçisi tarafından 15.4.1943 tarihinde CHP Genel Sekreterliği'ne sunulan halkevinin Şubat-Mart 1943 faaliyet raporu) yazışmalar)

3 Bkz: BCA, 490.01/1064.1083.3 (Londra Halkevi'nin faaliyet raporları ile ilgili

${ }_{114}$ BCA, 490.01/1064.1083.3 (Londra Halkevi Başkanlığı'nın CHP Genel Sekreterliği’ne gönderdiği 21.7.1942 tarihli yazı)

${ }^{115} \mathrm{Bu}$ ziyaretçiler arasında Şark Lisanları Mektebi öğretmen ve öğrencilerinden oluşan 70 kişilik bir grup, kız mekteplerine ait 100'den fazla öğretmen, 65 öğrenci ve Queen Collage'den 40 kişilik öğretmen ve öğrenci kafilesi ile çeşitli devlet kurumlarında çalışmak üzere genç kızları yetiştiren "Girls Training Corps"un mensupları da yer almaktadır. Bkz: $B C A, 490.01 / 1064.1083 .3$ (Londra Halkevi'nin faaliyet raporları ile ilgili yazışmalar) 
gazetecilerinin Londra'yı ziyareti vesilesiyle bazı İngiliz aydın ve gazetecilerinin de katıldığı bir davet düzenlenmiş ve bu davete yüzden fazla davetli katılmıştır ${ }^{116}$.

1942 yılının Eylül ve Ekim aylarında da Londra'daki çeşitli kurum ve kuruluşlara mensup İngiliz vatandaşları ile çeşitli nedenlerle Londra'da bulunan Türk vatandaşları halkevini ziyaret etmiş ve bu ziyaretler kapsamında çeşitli etkinlikler düzenlenmiştir ${ }^{17}$. Aynı yılın Aralık ayında pek çok kişi gruplar halinde halkevini ziyarete gelmiş ve ziyaretçilere çay ziyafeti verilmiş, Türkiye ile ilgili tanıtıcı konuşmalar yapılmış, sergiler gezdirilmiş ve film gösteriminde bulunulmuştur. Bu ay içerisinde halkevini grup halinde ziyaret eden kurum ve kuruluşlar arasinda Central School, Bethnal Green, Finsbury Ranger, London Apreication Society, South Wark Girls Training Corps, City Literary İnstitue, ST Alban's Churc, Acton Green gibi isimler yer almıştır ${ }^{118}$.

Halkevinin açı1ışını takip eden ilk bir yıllık süre içerisinde beş binden fazla kişinin halkevini ziyaret etmesi ${ }^{119}$; halkevinin gerçekleştirdiği faaliyetlere İngilizlerin ne derece yakın ilgi gösterdiğini, Türkiye ve Türk kültürü hakkında bilgi edinmek istediklerini ve halkevinin gerçekleştirdiğgi faaliyetlerin ziyaretçileri tatmin edici bir boyuta eriştiğini ortaya koymaktadır.

Londra Halkevi'ne gerçekleştirilen ziyaretler ve bu kapsamda düzenlenen çay ziyafeti, balo ve benzeri etkinlikler 1943 yılında bir önceki yıla göre daha yoğun bir şekilde sürdürülmüsstür. Bu yılın Ocak ayında İngiltere'nin Ankara Büyükelçisi Sir Hughe Knatchbull-Hugessen, halkevini ziyaret ederek bu kuruluşun varlığından duyduğu memnuniyeti dile getirmiştir ${ }^{120}$. Yine aynı ay içerisinde Associaton for Jewis Youth, Chiswick Cauntry School For Boys, West Kensingtion Central School, Stoke Newington Youth Clup ve Internatonal Women Services'den toplam 311 kişi halkevini ziyaret etmiştir. Bu ziyaretlerde çeşitli konuşmalar yapılmış, ziyaretçilere çay ziyafeti verilmiş ve Türkiye'yi tanıtmaya yönelik açılan sergiler gezdirilmiştir ${ }^{121}$.

${ }^{116}$ BCA, 490.01/1064.1083.3 (Londra Büyükelçiliği tarafından 28.9.1942 tarihinde CHP Genel Sekreterliği'ne gönderilen yazı)

${ }_{117} B C A, 490.01 / 1064.1083 .3$ (Londra Büyükelçiliği tarafından 2.12.1942 tarihinde CHP Genel Sekreterliği'ne sunulan halkevinin Ekim 1942 faaliyet raporu)

${ }_{118} B C A, 490.01 / 1064.1083 .3$ (Londra Büyükelçiliği' nden 11.1.1943 tarihinde CHP Genel Sekreterliği'ne sunulan halkevinin Aralık 1942 faaliyet raporu)

${ }_{19} B C A, 490.01 / 1064.1083 .3$ (Londra Büyükelçiliği tarafından 28.12.1944 tarihinde CHP Genel Sekreterliği'ne sunulan halkevinin ilk bir yıllık faaliyet raporu)

${ }^{120}$ Ayni rapor

${ }^{121} B C A, 490.01 / 1064.1083 .3$ (Londra Büyükelçisi tarafından 5.2.1943 tarihinde CHP Genel Sekreterliği'ne sunulan halkevinin Ocak 1943 faaliyet raporu) 
1943 yılının Şubat ayında da halkevine yüzlerce ziyaretçi gelmiş ve bu ziyaretçilere de daha önceki aylarda düzenlenen etkinlikler tekrarlanmıştır ${ }^{122}$. Aynı yılın Mart ayında halkevine yapılan ziyaretlerde ziyaretçilere çay ziyafeti verildikten sonra Sir Wyndham Deeds, Lady Govers ve Miss Fripp tarafından çeşitli konuşmalar yapılmıştır. Yine aynı ay içerisinde basın mensupları ve halkevi üyelerinin aralarında bulunduğu bir gruba; Atatürk, Londra Halkevi'nin faaliyetleri ve 19 Mayıs kutlamalarına ilişkin filmler izlettirilmiştir ${ }^{123}$.

Halkevine daha önceki aylarda olduğu gibi Nisan ayında da çeşitli okul, dernek ve kamu kuruluşlarından ziyaretçiler gelmiş ve bu ziyaretçiler için de benzeri etkinlikler düzenlenmiştir ${ }^{124}$. Mayıs ayında ise 8 farklı İngiliz kuruluşundan toplam 490 kişi ve Türk vatandaşlarından ise 50 kişi halkevini ziyaret etmiştir ${ }^{125}$.

Haziran 1943 'te halkevini ziyarete gelen, bir aylık ziyaretçi sayısı 800 'e kader yükselmişs ${ }^{126}$ ve bu ziyaretler yıl boyu devam etmiştir. Daha önce olduğu gibi bu ziyaretlerde de Türkiye hakkında çeşitli konuşmalar yapılmış, çay ziyafeti verilmiş, belgesel film gösteriminde bulunulmuş ve ziyaretçilere sergiler gezdirilmiştir. Londra Halkevi'ne gelen ziyaretçiler ve bu doğrultuda onlara Türkiye'yi ve Türk kültürünü tanıtmak için gerçekleştirilen etkinlikler, 1944 yılında da devam etmiştir. Ayrıca Türkiye'de bulunup da kısa süreliğine Londra'ya gelen veya Türkiye'ye gidecek olan İngiliz vatandaşları ve devlet adamlarının bazıları halkevini ziyaret ederek, Türkiye hakkında çeşitli bilgiler almıştır. Örneğin, 1944 yılında British Council'in İstanbul Şubesi Müdürü Mr. A.R. Thompson ile Britonova'nın İstanbul temsilcisi Mr. İ.A. Mackintosh, halkevini ziyaret etmiştir. Yine aynı yıl içerisinde İngiltere'nin Ankara Büyükelçisi Sir Maurice Peterson ile eşi şerefine Ankara'ya hareketlerinden önce halkevinde bir çay partisi verilmiştir. Bunların yanı sıra 1944 yılında Londra'da bulunan Türk vatandaşı öğrenciler, subaylar ve tüccarlar için çeşitli toplantılar ve ziyafetler düzenlenmiştir ${ }^{127}$.

Londra Halkevi'nin faaliyet raporlarından anlaşıldığı kadarıyla halkevini ziyaret eden İngilizlerin büyük bir çoğunluğunu öğretmen ve

${ }^{122}$ BCA, 490.01/1064.1083.3 (Londra Büyükelçisi tarafından 15.4.1943 tarihinde CHP Genel Sekreterliği'ne sunulan halkevinin Şubat-Mart 1943 faaliyet raporu)

${ }^{123} B C A, 490.01 / 1064.1083 .3$ (Londra Büyükelçisi tarafından 29.3.1943 tarihinde CHP Genel Sekreterliği'ne sunulan halkevinin Mart 1943 faaliyet raporu)

${ }_{124} B C A, 490.01 / 1064.1083 .3$ (Londra Büyükelçisi tarafından 24.4.1943 tarihinde CHP Genel Sekreterliği'ne sunulan halkevinin Nisan 1943 faaliyet raporu)

${ }^{125} B C A, 490.01 / 1064.1083 .3$ (Londra Büyükelçisi tarafından 31.5.1943 tarihinde CHP Genel Sekreterliği'ne sunulan halkevinin 1943 senesi Mayıs ayı faaliyet raporu)

${ }^{126} B C A, 490.01 / 1064.1083 .3$ (Londra Büyükelçisi tarafından 7.7.1943 tarihinde CHP Genel Sekreterliği'ne sunulan halkevinin Haziran 1943 faaliyet raporu)

${ }^{127} B C A, 490.01 / 1065.1086 .1$ (Londra Halkevi İstişare Komitesi tarafından Şubat 1945 'de CHP Genel Sekreterliği'ne sunulan 3. Senelik rapor) 
öğrenciler teşkil etmiștir. Bunun yanında Londra'da yaşayan çeşitli meslek gruplarında da halkevine gelenler mevcuttur. İngiliz dışişleri yetkilileri de zaman zaman halkevinin faaliyetlerine katılmıştır. İngilizlerin yanı sıra Londra'da yaşayan Türklerin de halkevine ilgi gösterdikleri anlaşılmaktadır. Ayrıca Londra Halkevi, Türkiye'den öğrenim için ya da başka amaçlarla Londra'ya giden Türkler için de bir dayanışma yeri işlevi görmüştür. Halkevi mensupları, özellikle öğrenim amacıyla Londra'ya gidenleri, ilgiyle karşılamıştır.

\section{g. Londra Halkevi Kütüphanesi}

Londra Halkevi açıldıktan kısa bir süre sonra, gerek İngilizlerin Türkiye, Türk tarihi ve kültürü hakkında bilgi edinebilmeleri gerekse Londra'da bulunan Türk vatandaşlarının istifade edebilmeleri amacıyla halkevi bünyesinde bir kütüphane oluşturulmuştur. Halkevinin açılışını takip eden ilk bir yıllık sürede Halkevi kütüphanesine 600'den fazla İngilizce, bir miktar Fransızca ve 100 kadar da Türkçe kitap temin edilmiştir ${ }^{128}$.

1944 y1lına gelindiğinde Halkevi kütüphanesinde 900'den fazla İngilizce, 450 kadar Türkçe ve bir miktar Fransızca kitap bulunmaktadır. Bunun yanı sıra İngilizce, Fransızca ve Türkçe birçok gazete ve dergi düzenli olarak halkevine getirilmiştir ${ }^{129}$.

1945 yılına gelindiğinde Halkevinin mevcut durumuyla ilgili bir rapor hazırlayarak CHP Genel Sekreterliği'ne gönderen Halkevi Başkanı Ruşen Eşref Ünaydın, halkevi kütüphanesinin kitap sayısının yetersiz ve bu kitapların nitelik bakımından oldukça zayıf olduğunu belirtmiştir. Ünaydın, söz konusu raporunda halkevi kütüphanesinin bir taraftan Londra'da bulunan Türk öğrenciler için önemli bir bilgi kaynağı olacağını, diğer taraftan ise Türkçe'ye meraklı İngilizler için Türk basını ve Türkiye'deki kültürel ve bilimsel çalışmaların tanıtılması açısından önemli bir merkez olması gerektiğini ifade etmiştir. Ünaydın, halkevi için gerekli olan kitapların Bakanlıklar, Basın-Yayın Direktörlüğ̈̈, CHP, dil ve tarih kurumları ve üniversiteler vasitasıyla kolayca temin edilebileceğini ifade etmiştir ${ }^{130}$. Ünaydın'ın bu talebinin ardından Londra Halkevi kütüphanesine kitap temin edebilmek amacıyla; CHP Genel Sekreterliği'nden fakültelere, bakanlıklara, diğer resmi kuruluşlara ve derneklere gönderilen yazılarla bu kuruluşların yayınlarından birer nüshanın halkevine gönderilmesi istenmiştir. CHP Genel

${ }^{128} B C A, 490.01 / 1064.1083 .3$ (Londra Halkevi'nin faaliyet raporları ile ilgili yazışmalar)

${ }^{129} B C A, 490.01 / 1065.1086 .1$ (Londra Halkevi İstişare Komitesi tarafından Şubat 1945 'de CHP Genel Sekreterliği'ne sunulan 3. Senelik rapor)

$130 B C A, 490.01 / 1065.1086 .1$ (Londra Halkevi Başkanı Rușen Essref Ünaydın'ın 27.03.1945 tarihinde CHP Genel Sekreterliği'ne halkevinin mevcut durumu ile ilgili sunduğu rapor) 
Sekreterliği’nin bu talimatının ardından halkevine pek çok kitap, gazete ve dergi gönderilmiştir ${ }^{131}$.

Londra Halkevi, kapatıldığında kütüphanesinin demirbaş defterine kayıtlı 1.410 Türkçe, 1.198 İngilizce, 95 Fransızca kitabın yanı sıra pek çok gazete ve dergi bulunmaktadır ${ }^{132}$.

\section{Londra Halkevi'nin İşlevini Yitirmesi ve KapatılsşS Süreci \\ a. Londra Halkevi'nin İşlevini Yitirmesinin Sebepleri ve Halkevini Canlandırmaya Yönelik Çalışmalar}

Londra Halkevi'nin ilk üç yıl içerisinde kuruluş amaçları doğrultusunda oldukça faal olduğu göze çarpmaktadır. Nitekim Londra Halkevi Başkanı Ruşen Eşref Ünaydın tarafından 27 Mart 1945 tarihinde CHP Genel Sekreterliği'ne gönderilen raporda, Londra Halkevi'nin 1945 yılına kadar geçen süre içerisinde Türkiye'yi ve Türk milletini bulunduğu muhitte tanıtma konusunda oldukça başarılı olduğu belirtilmektedir ${ }^{133}$.

Londra Halkevi'nin gerçekleştirdiği faaliyetlerde 1945 yılından itibaren önemli bir durgunluk yaşanmaya başlamıştır. Halkevlerinin 1945 yılı faaliyet broşüründe, Londra Halkevi'nin istenildiği doğrultuda faaliyette bulunamamasının sebeplerinden biri olarak II. Dünya Savaşı'nın ortaya koyduğu ağır koşullar nedeniyle bu halkevine gerektiği gibi yardım yapılamamış olması gösterilmektedir ${ }^{134}$. Bununla birlikte Londra Halkevi'nin özellikle 1946 yılından itibaren faaliyetlerini büyük ölçüde durdurmasının pek çok sebebi vardır. Londra Halkevi Başkanlığı'nın CHP Genel Sekreterliği'ne gönderdiği yazılardan, halkevinin mevcut durumunu tespit etmek için kurulan komisyonlara ait raporlarından ve çeşitli vesilelerle Londra'da bulunan CHP yöneticileri ya da müfettişleri tarafından CHP Genel Sekreterliği'ne gönderilen yazılardan hareketle, halkevinin niçin işlevini yitirdiğine ilişkin verilere ulaşılabilir. Ayrıca, bu raporlardan halkevini aktif hale getirebilmek için harcanan çabalar ve halkevinin kapatılma süreciyle ilgili aydınlatıcı bilgilere ulaşmak da mümkündür ${ }^{135}$.

${ }^{131} B C A, 490.01 / 1064.1084 .3$ (Londra Halkevi'ne gönderilmek üzere hazırlanan neşriyat hakkında yazışmalar)

${ }_{132} B C A, 490.01 / 1066.1088 .1$ (Dışişleri Bakanlığı'ndan 22.8.1950 tarihinde CHP Genel Sekreterliği'ne yazılan yazı)

${ }_{133}$ BCA, 490.01/1065.1086.1 (Londra Halkevi Başkanı Ruşen Eşref Ünaydın'ın 27.03.1945 tarihinde CHP Genel Sekreterliği'ne halkevinin mevcut durumu ile ilgili sunduğu rapor)

${ }^{134}$ CHP 1945 Yllında Halkevleri ve Halkodaları, Ankara 1946, s.10.

${ }^{135}$ Söz konusu yazı ve raporlar için bkz:; $B C A$, 490.01/1065.1086.1 (Londra Halkevi'nin genel durumu ve halkevi hakkında raporlar); $B C A, 30.10 / 117.817 .21$ (Londra Halkevi'nin durumu hakkında CHP Genel Sekreterliği'nin raporu); BCA, 30.10/117.817.20 (Londra Halkevi'ni inceleyen komisyonun raporu) 
Örneğin 1945 yilında halkevinin mevcut durumuyla ilgili bir rapor hazırlayarak CHP Genel Sekreterliği'ne gönderen Londra Halkevi Başkanı Ruşen Eşref Ünaydın, halkevinde eksik gördüğü noktaları sıraladıktan sonra bu eksikliklerin giderilmesi durumunda halkevinin Türkiye'yi sosyal, kültürel, ekonomik ve turistik açıdan en iyi şekilde tanıtılacağına inandığını ifade etmiştir ${ }^{136}$. Ünaydın'ın bu iyimser değerlendirmesine karşın CHP Genel Sekreteri ve Kırklareli Milletvekili olan Nafi Atuf Kansu ise 1946 yılında hazırladığ1 raporda halkevinin bir "Türk-İngiliz kulübü" olmaktan öteye gidemediğini ifade etmiştir ${ }^{137}$. Yine 1946 yılında Londra Halkevi'nin mevcut durumuyla ilgili bir rapor hazırlayan CHP Kars Milletvekili Tezer Taşkıran da, Londra Halkevi'nin kuruluş amaçlarına uygun olarak faaliyete geçirilmesinin İngiltere ve Türkiye arasındaki siyasi ve ekonomik ilișkiler göz önünde tutulduğunda Türkiye'nin tanıtılması ve Türk-İngiliz dostluğunun ilerletilmesi için gerekli olduğunu belirtmiştir. Tezer, yine aynı raporunda, halkevinin eğer işler hale getirilmezse faydadan ziyade zarar getireceğini, çünkü Londra'da Türkiye ve Türk kültürüne ilişkin ilk kanaati oluşturacak olan halkevinin Türkiye hakkında yanlış izlenimler uyandırabileceğini ifade etmiştî ${ }^{138}$.

1946’da Başbakanlığın talimatıyla kurulan ve Dışişleri Bakanı Hasan Saka, Milli Eğitim Bakanı Şemseddin Sirer ve Kırklareli Milletvekili N. Kansu tarafından oluşturulan komisyonun raporunda da; Londra Halkevi'nin Türkiye'yi tanıtmak, Türk milli kültürünü temsil etmek ve iki ülke arasındaki her türlü kültürel ilişkileri geliştirmek için şimdiye kadar ki faaliyetlerini sürdürmesi gerektiği belirtilmiştir. Bunun için ise CHP'nin halkevine gerekli olan bütün yardımları yapması gerektiği ifade edilmiştir. Söz konusu raporda, halkevinin farklı bir idari yap1 ve ad altında büyükelçiliğe ya da hükümete devredilmesi önerilerine sıcak bakılmayarak, bu kültür kurumunun yine "Halkevi" adı altında CHP'ye bağlı bir kuruluş olarak devam etmesinin uygun olacağı belirtilmiştir ${ }^{139}$.

1945 ve 1947 yılları arasında Londra Halkevi'nin tekrar faal hale getirmeye yönelik çabalar sonuç vermemişs ${ }^{140}$ ve halkevi bazı küçük

136 BCA, 490.01/1065.1086.1 (Londra Halkevi Başkanı Ruşen Eşref Ünaydın’ın 27.03.1945 tarihinde CHP Genel Sekreterliği'ne Halkevinin mevcut durumu ile ilgili sunduğu rapor)

${ }^{37}$ BCA, 030.10/117.817.21 (CHP Genel Sekreteri ve Kırklareli Milletvekili N. Kansu tarafından 11.2.1946 yılında Başbakan Şükrü Saraçoğlu'na sunulan rapor)

${ }_{138}$ BCA, 490.01/1065.1086.1 (CHP Kars Milletvekili Tezer Taşkıran'ın 3.12.1946 tarihinde CHP Genel Sekreterliği'ne sunduğu rapor)

$139 B C A, 03.10 / 117.817 .20 ; \mathrm{BCA}, 490.01 / 1065.1086 .1$ (Başbakanlı̆̆ın talimatıyla Londra Halkevi'nin durumunu incelemek üzere Dışişleri Bakanı Hasan Saka, Milli Eğitim Bakanı Şemseddin Sirer ve Kırklareli Milletvekili N. Kansu tarafından hazırlanarak 31.10.1946 tarihinde Başbakanlığa sunulan rapor).

140 Bkz: $B C A$, 490.01/1065.1086.1 (Londra Halkevi Başkanlığı tarafından 1 Temmuz 1947 tarihinde CHP Genel Sekreterliği’ne Sunulan İdare Heyeti Raporu) 
etkinliklerin dışında hiçbir faaliyet gösterememiştir. Buna karşın halkevini canlandırmaya yönelik girişimler 1948 ve 1949 yıllarında da sürdürülmüştür. Londra Halkevi'yle ilgili hazırlanan raporlar incelendiğinde, bu kuruluşun 1949 yılına gelindiğinde işlevini tamamen yitirmesi hatta fiilli olarak kapanmasının nedenleri ile CHP'li yöneticilerin çözüm önerilerini birkaç başlık altında toplamak mümkündür.

İdari Nedenler: Londra Halkevi'nin niçin faaliyet göstermediği ve nasıl faal hale getirilebileceğine ilişkin hazırlanan raporların hemen hepsinde idari nedenler başı çekmekte, bunlar içerisinde ise halkevi başkanının durumu gelmektedir. Söz konusu raporlara göre; aynı zamanda Londra Büyükelçisi olan halkevi başkanının ve asıl görevleri başka olan halkevi yönetim kurulu üyelerinin, halkevinin işlerine yeterince vakit ayıramaması ve halkevi yönetim kurulunda bulunanların büyükelçinin müsaadesini almadıkça hareket serbestîsine sahip olamamaları ${ }^{141}$ bu kuruluşun işlevini yitirmesindeki başlıca nedenler arasındadır. Bu soruna çözüm önerisi olarak ise, Londra Büyükelçisi'nin yalnızca fahri olarak halkevi başkanlığını yürütmesi, onun yerine ise sadece halkevinin işleriyle ilgilenecek, iyi İngilizce bilen, genel kültür seviyesi yüksek ve eski milletvekili ya da profesör unvanını taşıyan bir mesul müdür ya da başkanın atanması teklif edilmiştir $^{142}$. Halkevine müdür atanması önerisinin yanı sıra halkevi için İngiltere'nin şartlarına uygun bir yönetmeliğin hazırlanması ve daha önce olduğu gibi Türk ve İngilizlerden oluşan bir idare kurulunun oluşturulması da öneriler arasındadır ${ }^{143}$.

Londra'daki Türk Nüfusunun Azlı̆̆l: Halkevinin faaliyetlerini durdurmasına gösterilen gerekçelerden bir tanesi de, Londra gibi kalabalık bir şehirde sadece 50 civarında öğrenci ile az sayıda subay ve tüccardan oluşan Türk nüfusunun yer almasıdır ${ }^{144}$. Buradaki Türk nüfusunun azlığı; halkevi üye sayısının az olmasına, halkevinde gerçekleştirilecek olan

${ }^{141}$ BCA, 490.01/1065.1086.1 (CHP Maraş Milletvekili Hasan Reşit Tankut'un Londra Halkevi'nin mevcut durumuyla ilgili 27.8.1948 tarihinde CHP Genel Sekreterliği'ne gönderdiği rapor); $B C A, 490.01 / 1065.1086 .1$ (Emin Hekimgil'in Londra Halkevi'nin durumuyla ilgili Cumhuriyet Halk Partisi Genel Sekreterliği'ne 21.9.1948 tarihinde sunduğu rapor)

${ }^{142}$ BCA, 490.01/1065.1086.1 (CHP Kars Milletvekili Tezer Taşkıran'ın 3.12. 1946 tarihinde CHP Genel Sekreterliği'ne sunduğu rapor); $B C A, 490.01 / 1065.1086 .1$ (Emin Hekimgil'in Londra Halkevi'nin durumuyla ilgili Cumhuriyet Halk Partisi Genel Sekreterliği'ne 21.9.1948 tarihinde sunduğu rapor); $B C A, 490.01 / 1066.1088 .1$ (Milli Eğitim Bakanı Tahsin Banguoğlu tarafından 27.9.1949 tarihinde CHP Genel Sekreter Yardımcısı Cevat Dursunoğlu'na gönderilen yazı); BCA, 490.01/1065.1086.1 (CHP Genel Sekreteri ve Konya Milletvekili T. Fikri Sılay tarafından Başbakan Hasan Saka'ya sunulan tarihsiz rapor)

${ }_{143} B C A, 490.01 / 1065.1086 .1$ (CHP Kars Milletvekili Tezer Taşkıran'ın 3.12.1946 tarihinde CHP Genel Sekreterliği’ne sunduğu rapor)

${ }^{144} B C A, 490.01 / 1065.1086 .1$ (CHP Maraş Milletvekili Hasan Reşit Tankut'un Londra Halkevi'nin mevcut durumuyla ilgili 27.8.1948 tarihinde CHP Genel Sekreterliği'ne gönderdiği rapor); ayrıca bkz: BCA, 490.01/1066.1088.1 (CHP V. Büro Şefliğinden Genel Sekreterliğe gönderilen tarihsiz yazı) 
faaliyetlere gönüllü olarak katkıda bulunacak veya düzenlenen faaliyetlere katılacak olan insan potansiyelinden yoksun olunmasına sebep olmuştur. Ayrıca Londra'da bulunan Türk vatandaşları içerisinde önemli bir yer tutan öğrenciler, öğrenimlerinin olumsuz yönde etkilenmesi sebebiyle halkevinin yönetimine katkı sağlayamamıştır ${ }^{145}$.

Halkevi'nin Faaliyette Bulunabilmesi İçin Gerekli Vasıtalardan Yoksun Olmast: Londra Halkevi'nin faaliyetlerini durdurmasinda en temel nedenlerden biri olarak da halkevinin Türkiye'yi ve Türk kültürünü tanıtabilmesine yarayacak hemen her vasıtadan yoksun oluşu gösterilmiştir ${ }^{146}$. Örneğin, alanlarında uzman konferansçı bulmakta sıkıntı çekilmiştir. Ayrıca Türk kültürünü ve Türkiye'de çağdaşlaşma adına gerçekleştirilen gelişmeleri gösterecek sergi malzemelerinin ve belgesel filmlerin yetersizliğii, Türkiye'yi tanıtacak yayınların halkevine ulaştırılması, uzman eleman ihtiyacı ve halkevi binasının iyi bir şekilde döşeyecek gereçlerin yokluğu gibi eksiklikler halkevinin faaliyette bulunamamasının başlıca nedenlerinden birini teşkil etmiştir.

Hazırlanan raporlarda bütün bu eksikliklerin giderilmesine ilişkin pek çok öneride bulunulmuşsa da ${ }^{147}$ bu teşebbüsler yalnızca kâğıt üzerinde kalmış ve uygulamaya geçirilememiştir.

\section{b. Londra Halkevi'nin Kapatılması}

1949 yılına gelindiğinde Londra Halkevi bütün faaliyetlerini durdurmuş, Konya Milletvekili Muhsin Adil Binal'ın deyimiyle "ismi var, cismi yok" bir kurum haline gelmiştir ${ }^{148}$. Londra Halkevi'nin fiili olarak kapalı olmasına karşın 1949 yılında hazırlanan raporlarda, Türk-İngiliz ilişkilerinin seyri ve milli menfaatler açısından bu kurumun yaşatılması

${ }^{145}$ Londra Halkevi'nin ilk açıldı̆ğ dönemde halkevinin idaresine dâhil edilen Türk öğrenciler tahsillerine devam edememis ve sene kaybına uğramıștır. Bunun üzerine Londra Halkevi Başkanı Rauf Orbay tarafından bu öğrenciler, halkevi yönetiminden uzaklaştırılmışlardır. Bkz: $B C A$, 490.01/1065.1087.1 (Londra Büyükelçisi H. Rauf Orbay tarafından 16.10.1942 tarihinde CHP Genel Sekreterliği'ne gönderilen yazı)

${ }^{146}$ CHP Kars Milletvekili Tezer Taşkıran tarafından 3 Aralık 1946 yılında CHP Genel Sekreterliği'ne sunulan raporda; halkevinin faal olabilmesi için gerekli olan bütün vasıtalardan yoksun olduğunu, hatta iki odasının döşeli olmasına karşın bu odalarda elektrik olmaması nedeniyle Türkçe derslerinin mum ışı ğı altında verildiği ifade edilmiştir. Bkz: $B C A$, 490.01/1065.1086.1 (CHP Kars Milletvekili Tezer Taşkıran'ın 3.12. 1946 tarihinde CHP Genel Sekreterliği'ne sunduğu rapor)

${ }_{147}$ Londra Halkevi'ni faal hale getirebilmek için tespit edilen eksiklikler ve bu eksiklerin nasıl giderilebileceğine ilişkin öneriler için bkz: BCA, 490.01/1065.1086.1 (CHP Maraş Milletvekili Hasan Reşit Tankut'un Londra Halkevi'nin mevcut durumuyla ilgili 27.8.1948 tarihinde CHP Genel Sekreterliği'ne gönderdiği rapor); BCA, 490.01/1066.1088.1 (Milli Eğitim Bakanı Tahsin Banguoğlu tarafından 27.9.1949 tarihinde CHP Genel Sekreter Yardımcısı Cevat Dursunoğlu'na gönderilen yazı)

${ }_{148} B C A, 490.01 / 1065.1086 .1$ (Konya Milletvekili Muhsin Adil Binal tarafından Londra Halkevi'nin mevcut durumu ile ilgili 3 Mayıs 1949 tarihinde CHP Genel Sekreterliği'ne sunulan rapor) 
gerektiği ve halkevinin kapatılmasının Türkiye açısından çok kötü bir reklâm olacağı belirtilmiştir ${ }^{149}$. Ayrıca hazırlanan raporlarda Londra Halkevi'nin çok partili dönemde bu haliyle yanlış yorumlara yol açacağı ve yaşatılmayacağ ${ }_{1}^{150}$ belirtildikten sonra halkevinin bir "Türk Lokali" haline getirilerek halkevi binasının da Londra Büyükelçiliği'ne bağlı ataşeliklere verilmesi ${ }^{151}$ veya hükümete devredilmesi ${ }^{152}$ gibi önerilerde bulunulmuştur.

Londra Halkevi'ni tekrar faal hale getirmek için gerçekleştirilen teşebbüsler sonuçsuz kalmıştır. 1950'de fiili olarak kapalı bulunan Londra Halkevi'ni yaşatmanın artık anlamsız olduğu düşünüldüğü için, CHP'nin 9 Şubat 1950 tarihli Genel İdare Kurulu toplantısında halkevinin faaliyetlerine son verilmesi kararlaştırılmıştır ${ }^{153}$. Bu karar 15 Şubat 1950 tarihinde Londra Halkevi Başkanlığı'na gönderilen bir yazıyla tebliğ edilmiş ve "Londra'da geniş bir Türk kolonisi bulunmaması" sebebiyle beklenen faydayı sağlayamayan halkevinin faaliyetten kaldırılmasına karar verildiği belirtilmiştir ${ }^{154}$.

Halkevi 31 Mart 1950 tarihinde resmen kapatılmış ve son idare kurulu tarafından hazırlanan bir tutanakla 5 Nisan 1950 tarihinde Londra Büyükelçiliği'ne devredilmiştir ${ }^{155}$. Demokrat Parti'nin iktidara gelmesinden sonra ise, Londra Büyükelçisi ve elçilik mensupları halkevindeki görevlerinden ayrılmışlardır ${ }^{156}$. CHP Genel İdare Kurulu tarafından 11 Aralık 1950 tarihinde alınan bir kararla halkevinin borçlarının ve tamir masraflarının ödenmesi kaydıyla hükümete devredilmesi kararı alınmış ${ }^{157}$ ve gerekli devir teslim işlemlerinin başlatılması için durum Başbakanlığa bildirilmiştir $^{158}$. Sonuç olarak CHP ile Başbakanlık arasında süren bir takım yazışmaların ardından Londra Halkevi'nin binası hükümete devredilmiştir.

${ }^{149}$ BCA, 490.01/1066.1088.1 (Milli Eğitim Bakanı Tahsin Banguoğlu tarafından 27. 9. 1949 tarihinde CHP Genel Sekreter Yardımcısı Cevat Dursunoğlu'na gönderilen yazı)

${ }_{150} B C A, 490.01 / 1065.1086 .1$ (Konya Milletvekili Muhsin Adil Binal tarafindan Londra Halkevi'nin mevcut durumu ile ilgili 3 Mayıs 1949 tarihinde CHP Genel Sekreterliği'ne sunulan rapor)

${ }^{151} B C A, 490.01 / 1065.1086 .1 ; 490.01 / 1066.10881$ (CHP Genel Sekreteri ve Konya Milletvekili T. Fikri Sılay tarafından Başbakan Hasan Saka'ya sunulan 12.1.1949 tarihli rapor)

${ }^{152}$ BCA, 490.01/1065.1086.1 ( Konya Milletvekili Muhsin Adil Binal tarafindan Londra Halkevi'nin mevcut durumu ile ilgili CHP Genel Sekreterliği'ne sunulan rapor)

${ }^{153} B C A, 490.01 / 1066.1088 .1$ (CHP Başkâtipliğinden 10.2.1950 tarihinde VII. Büro Şefliğine gönderilen yazı)

${ }_{154}$ BCA, 490.01/1066.1088.1 (CHP Genel Sekreteri ve Konya Milletvekili T. Fikret Sılay tarafından 15.2.1950 tarihinde Londra Halkevi Başkanlığına gönderilen yazı)

${ }^{155} B C A, 490.01 / 1066.1088 .1$ (Dişişleri Bakanlığı'ndan 22 Ăğustos 1950 tarihinde CHP Genel Sekreterliği'ne yazılan yazı)

${ }_{156} B C A, 490.01 / 1066.1088 .1$ (CHP V. Büro Şefliğinden Genel Sekreterliğe gönderilen tarihsiz yazi)

${ }^{157} B C A, 490.01 / 1066.1088 .1$ (CHP'nin 11.12.1950 tarihli Genel İdare Kurulu kararı)

${ }^{158} B C A, 490.01 / 1066.1088 .1$ (CHP Genel Sekreterliği'nin Başbakanlığa 12.12. 1950 tarihli yazısı) 


\section{SONUÇ}

İngiliz Sir Wyndham Deeds'in teklifi ve British Council'in teşvikleri neticesinde 19 Şubat 1942 tarihinde açılan Londra Halkevi, yurt dışında açılan ilk ve tek halkevi olma özelliğine sahiptir. Ayrıca Londra Halkevi, Türkiye'nin yurt dışında açmış olduğu ilk "kültür kurumları"ndan biridir. Wydham Deeds ve CHP yöneticilerinin konuşma ve yazışmalarında bu kuruluşun temel amacı; Türkiye ve Türk kültürünü İngilizlere doğru bir şekilde tanıtmak ve iki ülke arasındaki kültürel ilişkileri geliştirmek olarak açıklansa da; özellikle İngilizlerin bu kuruluşu bir tür propaganda merkezi olarak düşündüğü ve Londra Büyükelçiliği'nin de buna engel olmaya çalıştığı görülmektedir. Bu bağlamda Türk-İngiliz ilişkilerinin seyri, bu kuruluşun gerçekleştirdiği faaliyetlere ve British Council'in bu kuruluşa yaklaşımlarını da etkilemiştir.

Londra Halkevi yöneticileri bu kuruluşu mümkün olduğunca siyasetin dışında tutmaya çalışmıştır. Nitekim halkevinin 1942-1945 yılları arasındaki faaliyetleri incelendiğinde, bu faaliyetlerin büyük çoğunluğunun Türkiye ve Türk kültürünü tanıtmaya yönelik olduğu görülecektir. Ayrıca halkevinin gerçekleştirdiği faaliyetlerde siyasi konulara temas edilmemiş olması, Büyükelçiliğin Londra Halkevi'ni bir siyasi propaganda merkezinden çok bir "Türk Kültür Merkezi” olarak düşündüğünü göstermektedir.

Londra Halkevi, yalnızca açılışını takip eden ilk üç yılda etkinlik gösterebilmiş ve 1946 yılından sonra işlevini yitirmeye başlamıştır. Bu yıldan sonra önemli bir varlık gösteremeyen Londra Halkevi'nin, 1950 yılına gelindiğinde resmi olarak faaliyetlerine son verilmiş ve böylece halkevleri arasında kapatılan ilk halkevi, Londra Halkevi olmuştur.

Türkiye'de açılan halkevlerinin başarıları ve o nispette halkın bu kuruluşlara gösterdiği teveccüh, CHP'yi yeni halkevleri açma noktasında cesaretlendirirken; Londra Halkevi teşebbüsünün önemli ölçüde başarısızlıkla sonuçlanması bu kuruluşların yurt dışında yenilerinin açılması açısından CHP idarecilerinin cesaretini kırmıştır.

Londra Halkevi, yoğun olarak faaliyet gösterdiği 1942-1945 yılları arasında kısa süreliğine de olsa Türk kültürünü ve yeni kurulan genç Türkiye Cumhuriyeti'nde gerçekleştirilen devrimleri İngilizlere tanıtmak ve anlatmakta başarılı olmanın yanı sıra; İngilizlerin gözündeki "yanlış Türk ve Türkiye imajı”nın değiştirilmesine küçük de olsa katkı sağlamıştır.

\section{KAYNAKÇA}

\section{Arşiv}

Başbakanlık Cumhuriyet Arşivi

BCA, 030.10/117.817.20 
BCA, 030.10/117.817.21

BCA, 490.01/1064.1083.1

BCA, 490.01/1064.1083.3

BCA, 490.01/1064.1084.1

BCA, 490.01/1064.1084.3

BCA, 490.01/1064.1084.4

$B C A, 490.01 / 1064.1083 .3$

$B C A, 490.01 / 1064.1086 .1$

$B C A, 490.01 / 1065.1087 .1$

$B C A, 490.01 / 1066.1088 .1$

BCA, 490.01/1064.1085.1

\section{Resmi Yayınlar}

CHF Halkevleri Talimatnamesi, Hâkimiyeti Milliye Matbaası, Ankara 1932.

CHP Halkevleri Öğrene ği, Recep Ulusoğlu Basımevi, Ankara 1938.

CHP Halkevleri İdare ve Teşkilat Talimatnamesi, Zerbamat Basımevi, Ankara 1940

CHP Halkevleri ve Halkodaları 1943, Ankara 1944.

CHP XVI. Yıldönümünde Halkevleri ve Halkodaları, Ulus Basımevi, Ankara 1948.

T.B.M.M. Tutanak Dergisi, C.9, Dönem IX, Toplantı 1, T.B.M.M. Basımevi, Ankara 1951.

CHP 1945 Yılında Halkevleri ve Halkodaları, Ankara 1946.

\section{Kitap ve Makaleler}

"Bütçe Görüşmeleri Dolayısıla B.M. Meclisi’nde Halkevleri Hakkında Konuşulanlar”, Ülkü, C.3, S.27, Mart 1949.

“Recep Bey’in Nutku”, Hâkimiyeti Milliye, 20 Şubat 1932.

Çeçen, Anıl, Atatürk'ün Kültür Kurumu Halkevleri, Cumhuriyet Yayınları, İstanbul 2000.

Kazmaz, Süleyman “Halkevleri ve Gençlik”, Ülkü, S.58 (Yeni Seri), Mart 1944.

Kongar, Emre, Atatürk ve Devrim Kuramları, Türkiye İş Bankası Kültür Yayınları, Ankara 1981. 
Öz, Esat, Otoriterizm ve Siyaset, Türkiye'de Tek Parti Rejimi ve Siyasal Katılma (1932-1945), Ankara 1996.

Özodaşık, Mustafa, Cumhuriyet Dönemi Yeni Bir Nesil Yetiştirme Çalışmaları 1923-1950, Çizgi Kitabevi, Konya 1999.

Sarınay, Yusuf, Türk Milliyetçiliğinin Tarihi Gelişimi ve Türk Ocakları, Ötüken Yayınları, İstanbul 2005.

Şimşek, Sefa, Bir İdeolojik Seferberlik Deneyimi Olarak Halkevleri 1932-1951, Boğaziçi Üniversitesi Yayınevi, İstanbul 2002

Tör, Vedat Nedim, Yıllar Böyle Geçti, Milliyet Yayınları, 1976.

http://www.britishcouncil.org/new/BritishCouncil75th/ 
EKLER

EK-1

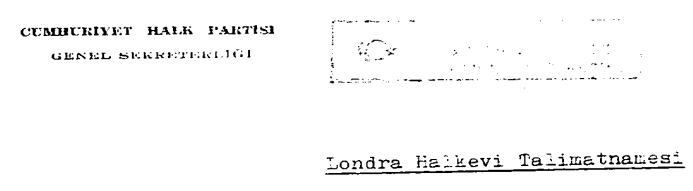

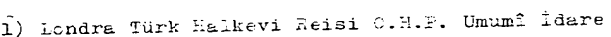
Feyetince tayin edilir. Reis kendisine ba heyeti kurar,

2) Infiiizlex, Feisin kabulid ile telkevinin fahrî azailérna kabul olurebilinzer.

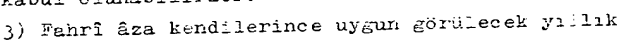
bir aiát verirler.

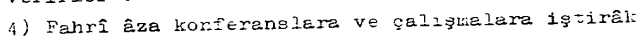
ve relkevi kïtiphenesinden isiffade ederier.

Londra Hazkevinin hesap işlerine ait talimat

1.- Londra furk fielkevirin biţ̧esi Büyiuk Elşilifin teklifi hizerine Genel Sekreterlisin tasvibi ile yürürǚ̆e girer. Her yila ait butcenin Eelir kismindaki (merkezden yercim) maddesine konulacak para cenel Sekreterlikse tesbit edilerek biidirilir.

2.- Londra Turk Huikevi Bütcesinin majajeierine fasıl-

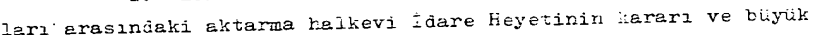
Elçinin uyoun görmesiyle yapilar.

3.- Gerek maî yili içerisinde elde edilen fazla beír gerekse kesin hesap biiânçosune göre ertesi seneye devredilen nakit bütçeye eklentekle beraber sarfedilmesi işin C.H.P. Genel Sekreterlizinin müsadesi alınr.

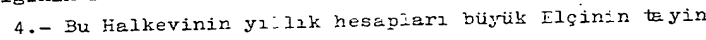
edecĕ̌i iki mirekip tarafinōan altı ayaje bir kontrol edilir. Murakipler tetkik ve teftis neticesini bir raporla Büyük Elçiye \begin{tabular}{|l|l|l|l|l|l|l|l|}
\hline 030 & 10 & 11 & 1 & 1 \\
\hline
\end{tabular}

BCA, 30.10/117.817.21 


\section{EK-2}

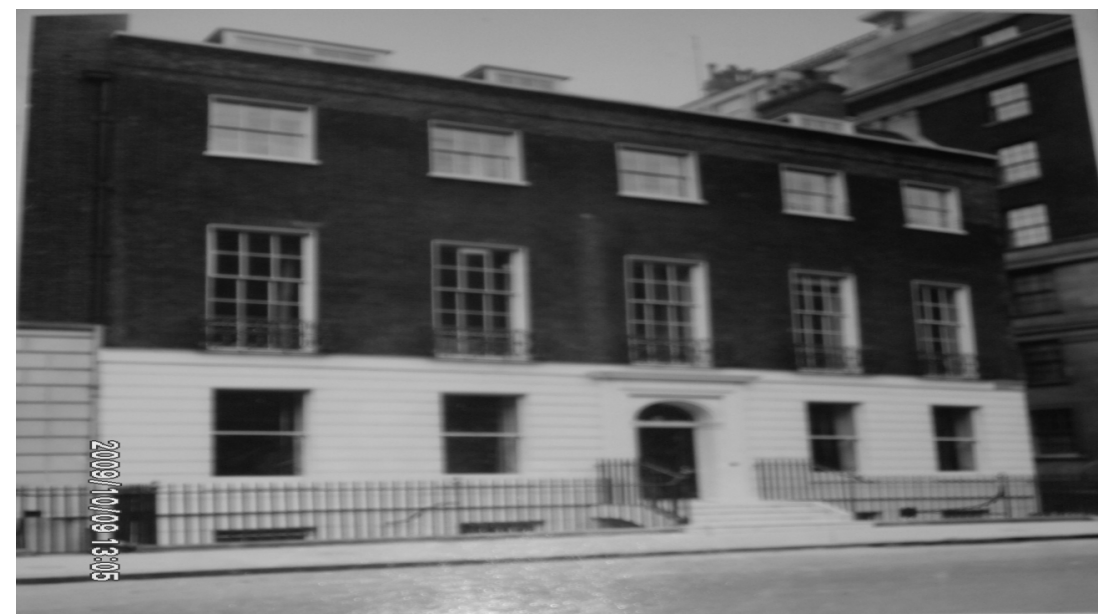

BCA, 490.01/1066.1088.1

Londra Halkevi'nin Fitzhardinge Caddesi 14 numarada bulunan ilk binasının dış cephesinden bir görüntü.

\section{EK-3}

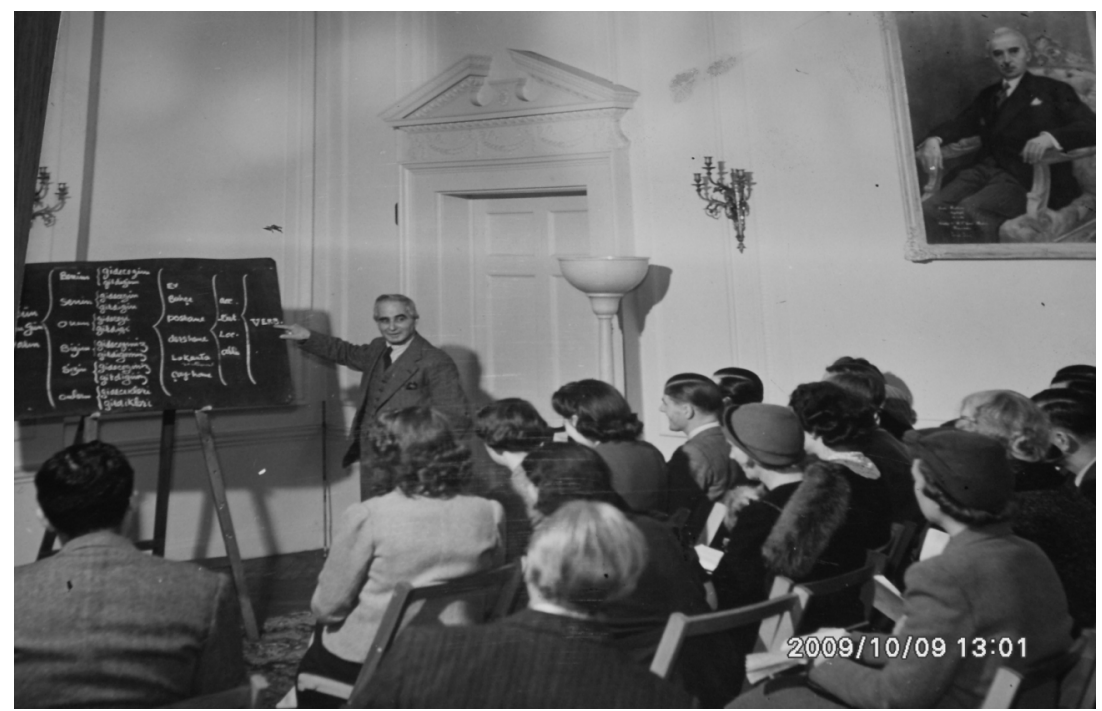

BCA, 490.01/1066.1088.1

Londra Halkevi Kâtibi Ali Rıza Şencan tarafından İngiliz kursiyerlere Türkçe dersi verilirken. 


\section{EK-5}

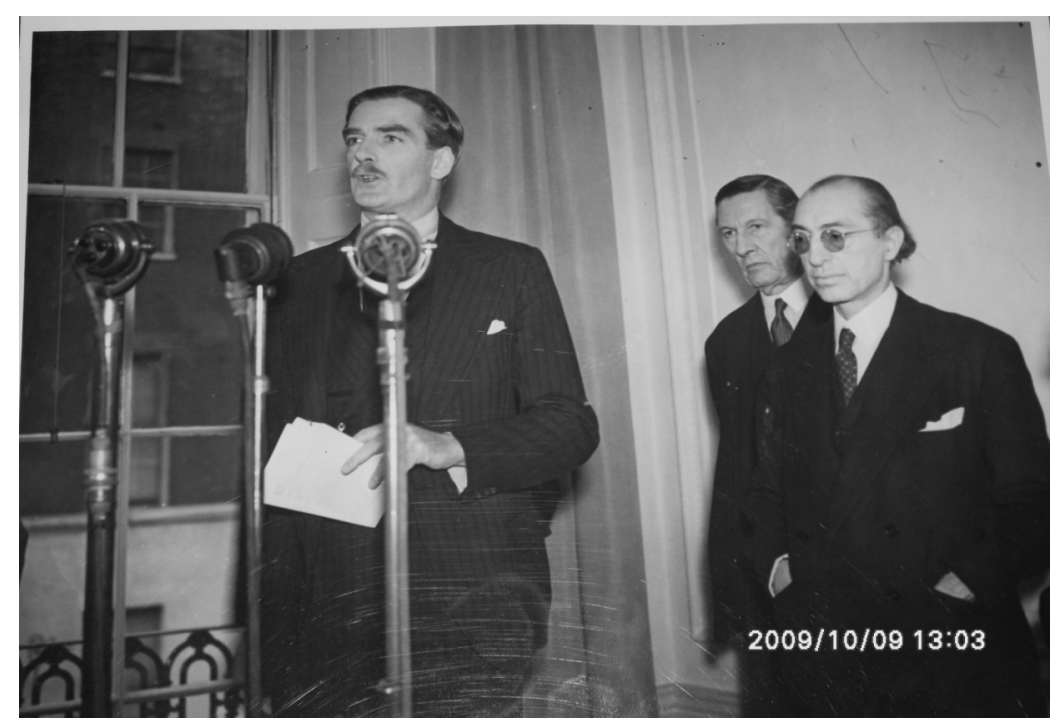

BCA, 490.01/1066.1088.1

İngiltere Dışişleri Bakanı Anthony Eden, 19 Şubat 1942 tarihinde Londra Halkevi'nin açılış töreninde konuşma yaparken.

EK-6

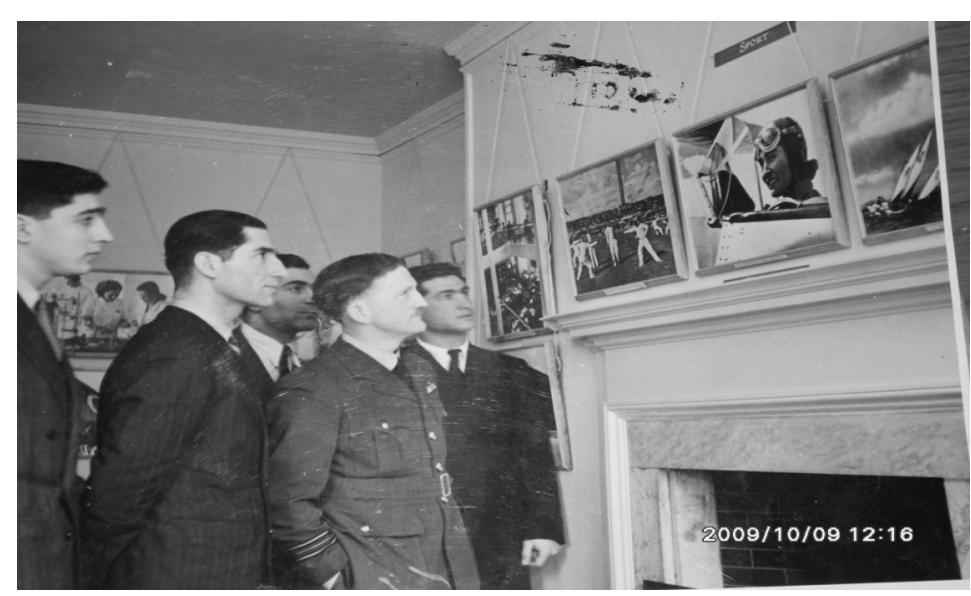

BCA, 490.01/1066.1088.1

Londra Halkevi'ne gelen bazı ziyaretçiler Türkiye'deki ilerlemeleri gösteren fotoğraf sergisini gezerken. 